\title{
Potential and limitations of multidecadal satellite soil moisture observations for selected climate model evaluation studies
}

\author{
A. Loew ${ }^{1}$, T. Stacke ${ }^{1}$, W. Dorigo ${ }^{2}$, R. de Jeu ${ }^{3}$, and S. Hagemann ${ }^{1}$ \\ ${ }^{1}$ Max Planck Institute for Meteorology, KlimaCampus, Hamburg, Germany \\ ${ }^{2}$ Department of Geodesy and Geo-Information, Vienna University of Technology, Vienna, Austria \\ ${ }^{3}$ Department of Earth Sciences, Faculty of Earth and Life Sciences, VU University Amsterdam, Amsterdam, the Netherlands
}

Correspondence to: A. Loew (alexander.loew @ zmaw.de)

Received: 15 February 2013 - Published in Hydrol. Earth Syst. Sci. Discuss.: 18 March 2013

Revised: 16 June 2013 - Accepted: 12 July 2013 - Published: 13 September 2013

\begin{abstract}
Soil moisture is an essential climate variable (ECV) of major importance for land-atmosphere interactions and global hydrology. An appropriate representation of soil moisture dynamics in global climate models is therefore important. Recently, a first multidecadal, observation-based soil moisture dataset has become available that provides information on soil moisture dynamics from satellite observations (ECVSM, essential climate variable soil moisture). The present study investigates the potential and limitations of this new dataset for several applications in climate model evaluation. We compare soil moisture data from satellite observations, reanalysis and simulations from a state-of-the-art land surface model and analyze relationships between soil moisture and precipitation anomalies in the different dataset. Other potential applications like model parameter optimization or model initialization are not investigated in the present study. In a detailed regional study, we show that ECVSM is capable to capture well the interannual and intraannual soil moisture and precipitation dynamics in the Sahelian region. Current deficits of the new dataset are critically discussed and summarized at the end of the paper to provide guidance for an appropriate usage of the ECVSM dataset for climate studies.
\end{abstract}

\section{Introduction}

Soil moisture is an essential climate variable (ECV) that has an impact on regional to global terrestrial water, energy and carbon fluxes. Soil moisture controls the partitioning of the available energy into latent and sensible heat flux and conditions the amount of surface runoff. By controlling evapotranspiration, it is linking the energy, water and carbon fluxes (Koster et al., 2004; Seneviratne and Stöckli, 2008) and has a direct feedback on precipitation (Taylor et al., 2012a) as well as temperature (Miralles et al., 2012; Mueller and Seneviratne, 2012) at the regional to global scale.

An appropriate knowledge of soil moisture conditions is important for the initialization and quality of seasonal to yearly climate predictions. Fischer et al. (2007) indicated that the record breaking European heat wave in 2003 was enhanced by the large soil moisture anomalies that were caused by a large precipitation deficit together with early vegetation green-up in the months preceding the extreme event. Loew et al. (2009) showed that these soil moisture anomalies were observable by remote sensing and Miralles et al. (2012) started to use satellite soil moisture anomalies to explain temperature extremes. All these studies indicate that due to its long-term memory, soil moisture can be an important factor for seasonal climate forecasts (Fischer et al., 2007).

Soil moisture shows a high variability from daily to interannual timescales and is therefore difficult to measure. Up to now, soil moisture observations are based on either in situ measurements (Robock et al., 2000; Dorigo et al., 2011) or satellite observations (Wagner et al., 1999; Njoku et al., 2003; Loew et al., 2006; Owe et al., 2008; Kerr et al., 2010). Several quasi-global soil moisture datasets have been developed during the last decade based on either active or passive microwave satellite observations from AMSR-E (Owe et al., 2008; Njoku et al., 2003), ERS AMI, MetOp ASCAT (Bartalis et al., 2007), SMMR, SSM/I, WindSat (Li et al., 2010; Parinussa et al., 2012) and SMOS (Kerr et al., 2010; Mecklenburg et al., 2012). Even though, except for SMOS, none of the used instruments has been specifically 
designed for soil moisture retrievals, the different products have been proven to show good correspondence with in situ observations over a large variety of environmental conditions (Draper et al., 2009; Gruhier et al., 2010; Brocca et al., 2011; Albergel et al., 2012; Dorigo et al., 2012b). They demonstrated their usefulness for applications like hydrological modeling (Beck et al., 2009; Brocca et al., 2012; Draper et al., 2012; Tramblay et al., 2012), numerical weather prediction (Drusch, 2007; Dharssi et al., 2011) or studies of land-atmosphere interactions (Seneviratne et al., 2010; Taylor et al., 2011, 2012a) as well as climate model evaluation and initialization (Schumann et al., 2009; Bisselink et al., 2011).

Recently, the first multidecadal satellite-based global soil moisture record (ECVSM) has become available (Liu et al., 2012). The new ECVSM data product has been generated by homogenizing different existing soil moisture products within the framework of the ESA's (European Space Agency) Water Cycle Multi-Mission Observation Strategy (WACMOS) project (Su et al., 2010).

The purpose of the present study is to evaluate potential applications of this novel soil moisture data record for climate model evaluation applications based on the land component of the Max Planck Institute for Meteorology Earth System Model (MPI-ESM). The overarching objectives of the analysis in this study are to

- evaluate the potential of using ECVSM satellite soil moisture observations for climate model evaluation at regional to global scales;

- analyze how ECVSM captures intra- and interannual soil moisture variability; and

- analyze how ECVSM can be used to study and evaluate the soil moisture and precipitation relationship and dynamics in observations and models.

This paper is the first study that provides a comprehensive analysis of potentials and limitations of the novel multidecadal soil moisture dataset for climate studies and climate modeling applications. It compares soil moisture data from a state-of-the-art land surface model, reanalysis as well as the novel ECVSM satellite-based soil moisture observations.

\section{Data and models}

\subsection{Soil moisture data}

\subsubsection{Multidecadal satellite soil moisture observations (ECVSM)}

The ECVSM product is the first ever multidecadal satellitebased soil moisture product and is available for the time period $1978-2010$ on a daily basis and at a spatial resolution of $0.25^{\circ}$. It has been generated by merging active and passive microwave-based soil moisture products (Wagner et al., 1999; Naeimi et al., 2009; Owe et al., 2008) from the following satellite instruments: SMMR (November 1978August 1987), SSM/I (July 1987-2007), TMI (1998-2008), AMSR-E (July 2002-December 2010), ERS-1/2 (July 1991May 2006), and ASCAT (2007-2010). The data harmonization procedure is described in Liu et al. (2012) and is based on a rescaling of the remote sensing soil moisture data using the soil moisture statistics from the Noah land surface model (Liu et al., 2011, 2012). A cumulative distribution function (CDF) matching technique is employed for that purpose. The CDF matching is applied on each grid cell individually and rescales the satellite observed soil moisture to the Noah land surface model statistics. As a consequence, the soil moisture statistics of the ECVSM data product is similar to that of the Noah land surface model. While this rescaling affects the percentile distribution of the ECVSM product, the temporal structures (e.g., autocorrelation, trends) are not changed by this rescaling approach (Liu et al., 2012).

Dorigo et al. (2012b) provide a comprehensive validation of ECVSM using 932 in situ observation sites from 29 different observing networks (Dorigo et al., 2011, 2013). Despite the large difficulties in validating coarse resolution satellite soil moisture products with in situ point-like observations (Crow et al., 2012), Dorigo et al. (2012b) conclude that the ECVSM product has an average unbiased RMSD (root mean square deviation) of $0.05\left[\mathrm{~m}^{3} \mathrm{~m}^{-3}\right]$ on daily timescales and mean correlation of $r=0.5$. Besides, it was shown that trends in ECVSM largely agree with those in various reanalysis products of precipitation, and vegetation vigor (Albergel et al., 2012; Dorigo et al., 2012a).

The ECVSM dataset provides a multitude of quality flags and only reliable soil moisture estimates are preserved in the data product. Snow covered areas or frozen ground are typically masked as well as dense or heterogeneously vegetated areas with high optical depth that are not expected to provide reliable soil moisture estimates (Loew, 2008; Parinussa et al., 2011). A pre-processing of the ECVSM data product is required to match it in space and time with the other datasets used in the present study. Thus, the ECVSM soil moisture data is regridded to the MPI-ESM T63 model grid $\left(\approx 1.85^{\circ}\right)$. A conservative remapping technique is used for that purpose, which is implemented in the climate data operators (cdo, https://code.zmaw.de/projects/cdo). Some data gaps were removed by this procedure due to spatial interpolation.

\subsubsection{MPI-ESM land surface model (JSBACH)}

MPI-ESM couples processes in the atmosphere, ocean and land surface through the exchange of momentum, water, energy and important trace gases such as carbon dioxide. It has been widely used for comparative model calculations in the context of the Coupled Model Intercomparison Project 5 (CMIP5) (Taylor et al., 2012b). 
The land surface component of MPI-ESM, JSBACH (Raddatz et al., 2007; Brovkin et al., 2009; Reick et al., 2013), is implicitly coupled to the atmospheric component of MPIESM, ECHAM6 (Stevens et al., 2013) and simulates all relevant land surface water, energy and carbon fluxes. The present study uses version 2.03 of JSBACH, which is comparable to the model version that was used for CMIP5 experiments, but which includes a layered soil hydrology scheme instead of a standard bucket scheme. In this version, the soil moisture dynamics in the unsaturated zone are simulated using five discretized soil layers with a thickness of $\mathrm{d} z=(0.065$, $0.254,0.913,2.902,5.7)[\mathrm{m}]$. For the present study, the first soil layer is used for comparison. A validation of global-scale energy and water flux components of MPI-ESM CMIP5 simulations is given in Hagemann et al. (2013) and Brovkin et al. (2013).

JSBACH can be either forced by any kind of meteorological data (e.g., station measurements, reanalysis data) or by coupling JSBACH directly to a global circulation model (GCM), like ECHAM6. For the present study, we use JSBACH in an offline mode, thus not coupled to a GCM. The model simulations were conducted for a $31 \mathrm{yr}$ period (19792009) using an offline forcing dataset. This allows for a more realistic comparison of satellite soil moisture observations with the model simulations as it minimizes the effect of precipitation errors. MPI-ESM model simulations are performed on a Gaussian model grid with rather coarse spatial resolution $\left(\mathrm{T} 63 \approx 1.85^{\circ}\right)$.

\section{Watch forcing data (ERA-interim), WFD(EI)}

The model forcing data used in the present study is based on a methodology created in the EU WATCH project (http: //www.eu-watch.org) and merges in situ observations with reanalysis data (Weedon et al., 2011). The WFD is based on corrected ERA40 (ECMWF Re-Analysis $40 \mathrm{yr}$ ) reanalysis data (Uppala et al., 2005). An elevation correction was applied for most variables. Furthermore, rainfall and snowfall were subject to extensive corrections to remove biases in the reanalysis data. An undercatch correction was applied for precipitation to ensure that the monthly statistics are similar to in situ observations of the Global Precipitation Climatology Centre (Schneider et al., 2008) while the daily variability of the reanalysis data is retained (Weedon et al., 2011). The forcing data used in the present study (WFDEI) was generated applying the WFD methodology to the ERA-interim reanalysis (Dee et al., 2011) data (Weedon et al., 2011). The WFDEI dataset covers the period 1979-2009 so far on a resolution of $0.5^{\circ}$. In order to serve as meteorological input for JSBACH it was regridded to T63 resolution.

\subsubsection{ERA-interim soil moisture}

ERA-interim is the latest global reanalysis of the European Centre for Medium Range Weather Forecasts (ECMWF).
It covers the period from 1979 until present and is based on a variational data assimilation system that assimilates a multitude of in situ and satellite observations in a consistent framework (Dee et al., 2011).

Soil moisture is a prognostic variable in ERA-interim and is provided for four soil layers with a thickness of $0.07,0.21$, 0.72 and 1.89 [m], respectively. The ERA-interim soil moisture data was extracted from the ERA-interim data archive for the period 1979-2009 and regridded to the same spatial grid as MPI-ESM using conservative remapping. For the present study the first soil layer is used for the analysis. As ERA-interim data is available every $6 \mathrm{~h}$, daily mean soil moisture fields were calculated by averaging data for each day and monthly means were calculated subsequently from the daily means.

\subsection{Precipitation data}

The precipitation data used in the present study comprise different data sources. Precipitation information from a satellite-based product as well as reanalysis data and a bias corrected reanalysis product are used for comparison of precipitation with soil moisture dynamics. The satellite-based product and bias-corrected reanalysis dataset use a common in situ dataset to correct for monthly biases in the precipitation record.

\subsubsection{GPCP}

The Global Precipitation Climatology Project (GPCP, v2.2) data product is based on satellite observations (Adler et al., 2003,2011 ). The monthly product used in this study has a spatial resolution of $2.5^{\circ} \times 2.5^{\circ}$ and provides data since 1979. It is based on a blended gauge-satellite product that combines precipitation retrievals from polar-orbiting passive microwave imagers (SSM/I) as well as geostationary observations (IR data). The satellite retrievals are further bias-corrected using rain gauge data from the Global Precipitation Climatology Centre's (GPCC) Monitoring Product (Schneider et al., 2008).

\subsubsection{ERA-interim precipitation}

The ERA-interim precipitation is produced by the ERAinterim forecasting model based on temperature and humidity information as derived by the assimilation of atmospheric and terrestrial observations. Total precipitation estimates are only available for forecasting time steps at 00:00 and 12:00 UTC. The $12 \mathrm{~h}$ segment following each forecast step is used to obtain daily estimates of the rainfall rate by integrating all forecast steps within the time periods 00:00-12:00 and 12:00-24:00 UTC. This sampling approach is similar to that of Dee et al. (2011). In general, ERAinterim overestimates precipitation especially in tropical regions compared to GPCP (Dee et al., 2011). As reanalysis precipitation is model generated, it also suffers from biases 
in annual or seasonal means over different regions (Lorenz and Kunstmann, 2012). The constraints imposed on precipitation by the data assimilation of other variables leads to reasonable variabilities, especially on a day-to-day basis, which is, e.g., utilized in the WFD and WFDEI. The usage of different observing systems in the data assimilation of re-analyses may lead to different biases or spurious trends (Hagemann et al., 2005) and should therefore be interpreted very carefully. The original ERA-interim spatial resolution $\left(\approx 0.7^{\circ}\right)$ was resampled to the T63 grid of MPI-ESM $\left(\approx 1.85^{\circ}\right)$ for further analysis.

\subsubsection{WFDEI precipitation}

The WFDEI data is based on ERA-interim reanalysis data that was corrected using in situ gauge information. It thus mediates between ERA-interim and GPCP datasets, which are solely based on observations or reanalysis data.

WFDEI combines ERA-interim reanalysis rainfall data with the version 4 of the GPCC rain gauge product (Schneider et al., 2008). After a gauge undercatch correction and an adjustment of wet days based on the CRU TS2.1 observations (New et al., 1999, 2000; Mitchell and Jones, 2005), the GPCCv4 product is used to correct for monthly biases in the reanalysis precipitation data while the temporal dynamics is preserved from the reanalysis fields. Thus, the WFDEI accounts for systematic known weaknesses in the reanalysis datasets like an overestimation of wet days in the tropics (Uppala et al., 2005).

\section{Methods}

The data in the present study corresponds to geospatial data that can be represented by a matrix $\mathbf{X}_{m \times n}=\left(x_{1}, \ldots, x_{n}\right)$ whereas $m$ corresponds to the number of time steps and $n$ to the number of grid cells. Each column vector $x_{k}, k \in 1, \ldots, n$, corresponds to a time series of soil moisture or precipitation. Monthly means are calculated for $x_{k}$ from all valid samples.

\subsection{Definitions}

\subsubsection{Calculation of anomalies}

Anomalies of precipitation and surface soil moisture are calculated by removing the mean seasonality from the monthly mean time series $x_{l, j}$ whereas $l \in(1,2, \ldots, 12)$ is an index for the month and $j$ is an index for the year. The anomaly time series $x_{l, j}^{\prime}$ is given by

$x_{l, j}^{\prime}=x_{l, j}-\bar{x}_{l, j}=x_{l, j}-\frac{1}{n} \sum_{k}^{n} x_{l, k}$

whereas $n$ is the number of years used to calculate the anomaly time series. All analysis presented in this study will be based on anomalies. Note that a linear detrending of the time series will be applied in some cases prior to calculating the monthly anomaly time series to avoid spurious correlations due to similar temporal long-term trends.

\subsubsection{Correlation and partial correlation analysis}

The Pearson product-moment correlation coefficient is used as a measure for linear correlation between the different soil moisture and precipitation datasets. The correlation coefficient between two variables of size $m$ is calculated as

$\rho_{x y}=\frac{\sum_{i=1}^{m}\left(x_{i}-\bar{x}\right)\left(y_{i}-\bar{y}\right)}{\sqrt{\sum_{i=1}^{m}\left(x_{i}-\bar{x}\right)^{2}} \sqrt{\sum_{i=1}^{m}\left(y_{i}-\bar{y}\right)^{2}}}$.

Precipitation is the major forcing for soil moisture variability. Soil moisture dynamics is however also affected by, e.g., soil hydraulic properties, vegetation or evapotranspiration. Partial correlation analysis is therefore used in addition to the general linear correlation analysis to analyze the general skill of ECVSM to capture the soil moisture dynamics. Partial correlation corresponds to the correlation of two datasets $(x, y)$ where the effect of an additional controlling variable $(z)$ has been removed. Formally, the partial correlation coefficient between variables $x$ and $y$ removing the effect of the controlling variable $z$ is given by

$\rho_{x y \mid z}=\frac{\rho_{x y}-\rho_{x z} \rho_{z y}}{\sqrt{1-\rho_{x z}^{2}} \sqrt{1-\rho_{z y}^{2}}}$.

Partial correlation analysis is used in the present study to investigate the relationship between two soil moisture datasets under the condition that the variability due to the rainfall dynamics has been removed before comparing the soil moisture datasets. This gives additional insight into the capabilities of ECVSM to represent soil moisture dynamics independent of precipitation dynamics.

\subsubsection{Percentile correlation}

The percentile distribution of soil moisture gives insight into the spatial patterns of temporal soil moisture dynamics as represented in either the simulated or observed soil moisture fields. The percentiles are derived from the probability density function, which is constructed from the time series of each grid cell individually. The advantage of comparing two soil moisture datasets by their percentile distribution is that it is independent from the absolute soil moisture values, but addresses only the similarity of relative soil moisture dynamics.

The $p$-th percentiles $p(p)$ of a dataset with $p \in(0.05$, $0.1, \ldots, 0.95)$ are calculated from the time series $x$ for each grid cell, which results in a spatial map, stored in a vector of size $n$ for each $p(p)$. The similarity between the percentile maps of the $p$-th percentile of two variables is then calculated as the linear correlation $\rho\left(p_{x}(p), p_{y}(p)\right)$. 


\subsection{An example application of ECVSM for regional climate studies}

The capability to capture significant climate anomalies is a crucial property of an ECV data record. It has been shown that satellite-based surface soil moisture records are capable to capture well the regional drought and flooding events like, e.g., the 2011 droughts in Australia, in the Horn of Africa and in the southern US (de Jeu et al., 2012).

The devastating drought in Africa's Sahel belt during the last half of the 20th century has been one of the largest and longest climate anomalies observed so far during the satellite era. The negative precipitation anomalies started in the 1960s with a minimum around 1980 (Fig. 1). Since this minimum, the rainfall recovered and it has been shown in various studies that the vegetation in the Sahel recovered subsequently (Olsson et al., 2005; Hickler et al., 2005; Fensholt et al., 2012).

Land surface-atmosphere feedbacks are likely to have been enhanced the Sahelian drought (Charney et al., 1977; Zeng, 1999) and it has been shown that soil moisture patterns affect the convective precipitation in this region (Taylor et al., 2011).

The ECVSM dataset is the first ever available multidecadal observation-based soil moisture data product that allows one to investigate the relationship between soil moisture, precipitation and vegetation dynamics in the Sahel for over three decades and to compare the observations against model simulations.

The present study investigates how the Sahelian drought event is captured by ECVSM and the other soil moisture and precipitation datasets. It will be evaluated if the ECVSM dataset provides suitable information to support regional climate studies on interannual to multidecadal timescales in the Sahel.

In this study, the Sahelian belt is subdivided in five subregions to capture different precipitation regimes in the region (Fig. 1). The longitudinal division follows Huber and Fensholt (2011) and Lebel and Ali (2009).

\section{Results}

\subsection{Spatiotemporal data coverage}

The ECVSM dataset has data gaps that are due to varying temporal and spatial coverage of the observations as well as different quality of the input data. Especially in the first decade of the ECVSM dataset, a large number of data gaps occurred due to the poor spatial coverage of the satellite instruments (Fig. 2). In the first pentad of the 1980s, nearly $50 \%$ of the year was without any data coverage, which was mainly due to the small swath width of the used satellite instruments (Nimbus-SMMR) and a reduction of imaging capabilities due to power constraints of the satellite. This
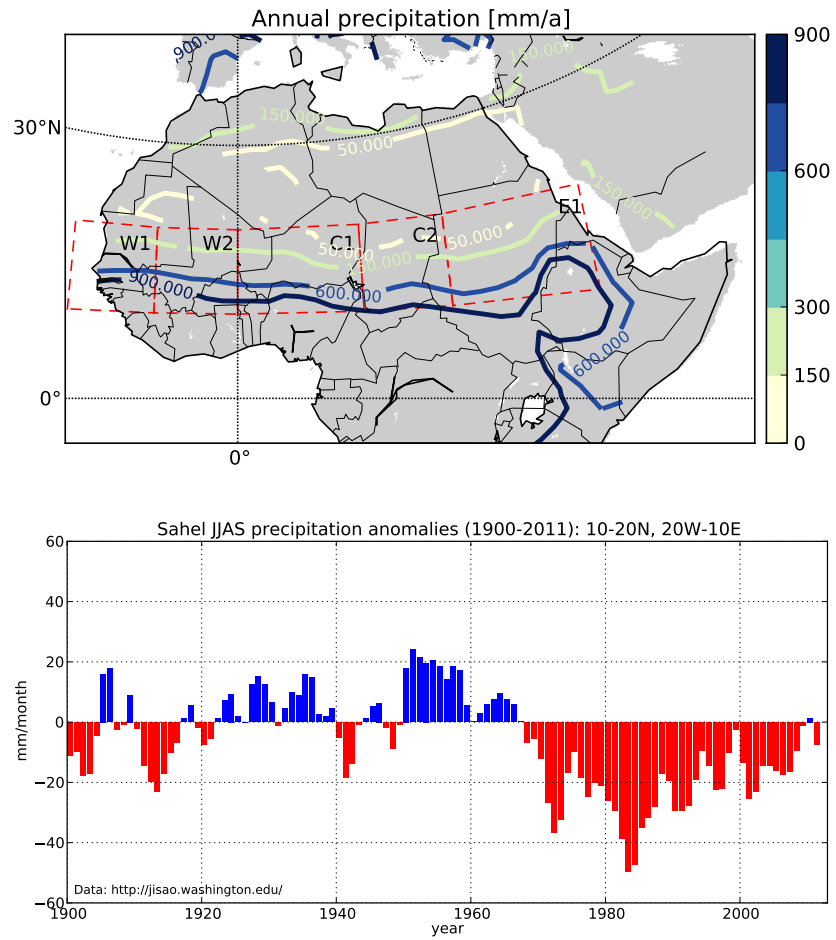

Fig. 1. Annual mean precipitation $\left[\mathrm{mm} \mathrm{yr}^{-1}\right]$ in the Sahelian region. Bounding boxes for regions used for detailed analysis extend between 10 and $20^{\circ} \mathrm{N}$. Longitudinal extent is given as $\mathrm{W} 1(20$ $\left.10^{\circ} \mathrm{W}\right), \mathrm{W} 2\left(10-00^{\circ} \mathrm{W}\right), \mathrm{C} 1\left(00^{\circ} \mathrm{W}-15^{\circ} \mathrm{E}\right), \mathrm{C} 2\left(15-25^{\circ} \mathrm{E}\right)$, and E1 $\left(25-40^{\circ}\right.$ E) (data: GPCP) (top panel). Sahel rainfall anomalies for the period 1900-2011 and the region from $10-20^{\circ} \mathrm{N}, 20^{\circ} \mathrm{W}-$ $10^{\circ} \mathrm{E}$ (data from http://jisao.washington.edu/, Ali and Lebel, 2009) (bottom panel).

explains why a large portion of the globe contains a large fraction of data gaps (Fig. 2). In northern latitudes, the fraction of missing data exceeds $80 \%$ of all days of the period 1978-2009. Figure 2 shows further the fraction of missing data for the ESA ECVSM dataset in different preprocessing steps. The raw ECVSM data contains on average a data gap fraction of $73 \%( \pm 17 \%)$; parentheses indicate standard deviations. The remapping of the dataset to T63 resolution decreases the fraction of data gaps to $60 \%( \pm 16 \%)$. For many applications, time series without gaps are required, which might be achieved, e.g., through temporal smoothing. Figure 2 shows also the effect of a 5 day running mean temporal smoothing filter on the data coverage which, is significantly improved (missing data: $30 \pm 23 \%$ ).

\subsection{Comparison of surface soil moisture dynamics}

\subsubsection{Global mean fields}

The global mean soil moisture is $0.18 \pm 0.09,0.2 \pm 0.07$ and $0.22 \pm 0.09$ for JSBACH, ECVSM and ERA-interim, respectively. ECVSM and JSBACH show a temporal variability 


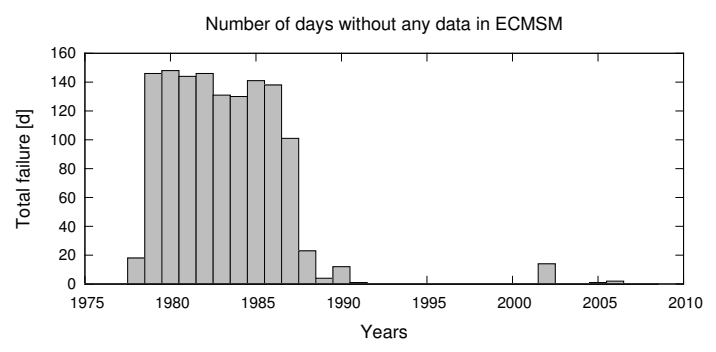

Fraction of missing soil moisture data for period 1979-2010 [days/days]
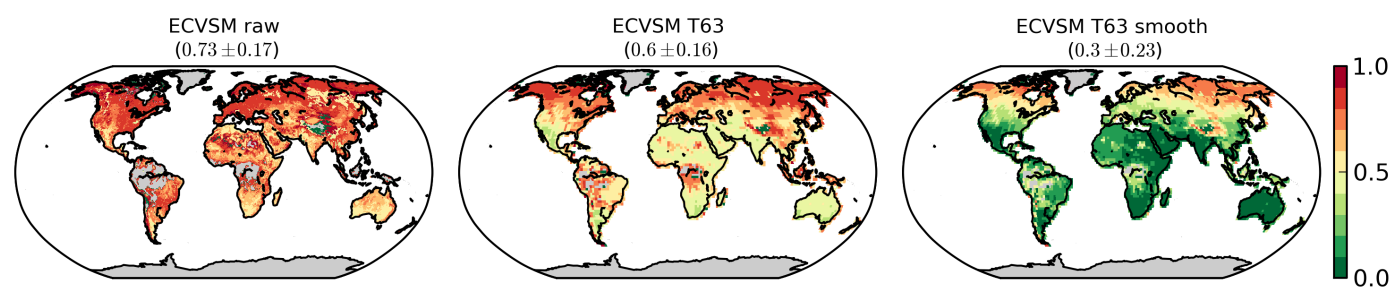

Fig. 2. Number of days per year without any soil moisture observations globally in ECVSM (top panel); fractional coverage of missing data for ECMSM in different pre-processing steps: raw: data at original spatial and temporal resolution, T63: data remapped to T63 grid, smooth: time series smoothed with 5 day running average kernel. Numbers in the figure titles indicate global mean and stdv (bottom panels).

that is closer to each other than to that of the ERA-interim, which has a much smaller temporal variability than the other datasets. The global mean coefficient of variation is almost half as large for ERA-interim $\left(\mathrm{CV}_{\mathrm{ERA}} \approx 0.12\right)$ as for JS$\mathrm{BACH}\left(\mathrm{CV}_{\mathrm{JSB}} \approx 0.24\right)$ and $\mathrm{ECVSM}\left(\mathrm{CV}_{\mathrm{ECV}_{\mathrm{SM}}} \approx 0.2\right)$.

Figure 3 shows distinct differences in the spatiotemporal zonal mean soil moisture fields and its anomalies. The biases between the different datasets are clearly observable. JSBACH shows a more pronounced seasonal cycle in the subtropical areas while ECVSM and ERA-interim show a smaller variability in these areas.

While the simulated soil moisture fields are homogeneous over time, the ECVSM dataset clearly shows inconsistencies in the time series. A drying of the zonal mean soil moisture is for instance observed in 2002. Further discontinuities can be observed in 1987 and 2006. These discontinuities are also observable in the anomaly plots, which show in general much stronger amplitudes for ECVSM than for ERA-interim or JSBACH.

As discontinuities in ECV time series can easily introduce artificial trends in time series that could be misinterpreted as a climate signal, a careful analysis of such kind of time series is important (Loew and Govaerts, 2010). In particular, a much more thorough analysis of the causes and effects of the observed discontinuities on data analysis is needed, which is beyond the scope of the present study. It is however emphasized that a careful treatment of trends derived from ECVSM is necessary.

\subsubsection{Correlation between soil moisture fields}

Figure 4 shows the correlation distribution between the monthly mean surface soil moisture of different datasets as well as the distribution and maps of the correlation between their anomalies. Highly significant correlations are observed between all datasets, which indicates in general a good skill of all datasets to represent the interannual and seasonal surface soil moisture variability in a consistent way. Larger differences are observed in the northern latitudes, caused by the poor data coverage in ECVSM due to snow and frozen soil conditions. Negative correlations are here especially observed between ECVSM and both models.

While both models show also significant positive correlations in the tropical areas with dense vegetation like the Amazon or Congo basins, the ECVSM does not show any significant correlations in these areas with either of the model datasets. This was expected, as the remote sensing signal is perturbed by dense vegetation and the microwave signal is lacking any soil moisture information in these areas (Jeu et al., 2008; Dorigo et al., 2010). The global mean correlations between soil moisture anomalies of ECVSM and JSBACH (ERA-interim) are $\rho=0.41 \pm 0.2(\rho=0.36 \pm 0.19)$ while the anomaly correlation between the model simulations is higher $(\rho=0.64 \pm 0.2)$. Thus, in areas where the microwave signal is in general sensitive to soil moisture dynamics, the ECVSM dataset shows reasonable agreement with the two simulated soil moisture datasets for both, absolute values as well as for the soil moisture anomalies. A more detailed comparison of the soil moisture statistics of the different datasets will be made in the following by analyzing the soil moisture percentile distribution.

\subsubsection{Percentiles of soil moisture dynamics}

The percentiles of the soil moisture were calculated from the time series of each dataset for each grid cell. Figure A1 

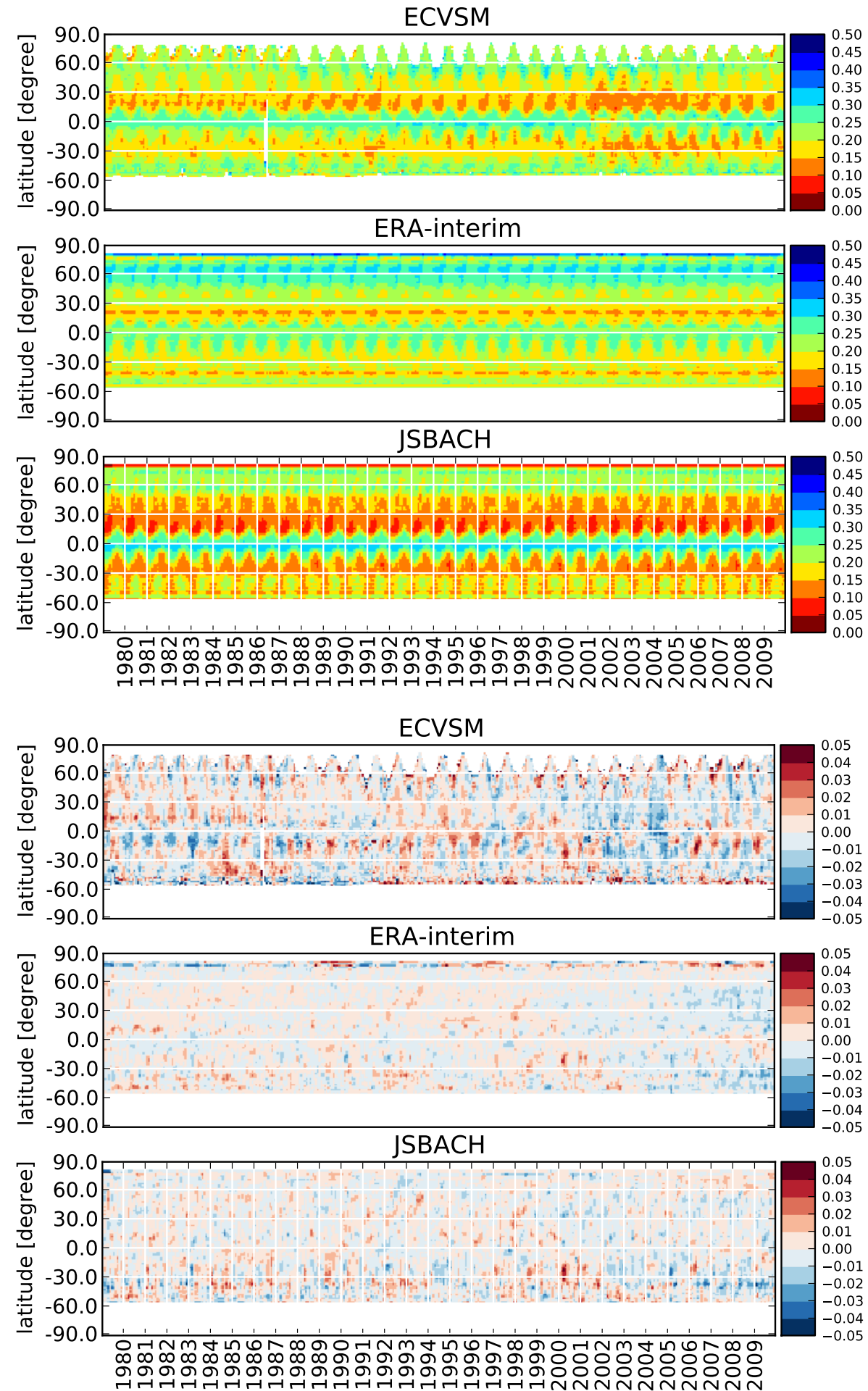

Fig. 3. Time-latitude diagrams for monthly mean volumetric surface soil moisture and surface soil moisture anomaly datasets $\left[\mathrm{m}^{3} \mathrm{~m}^{-3}\right]$. 

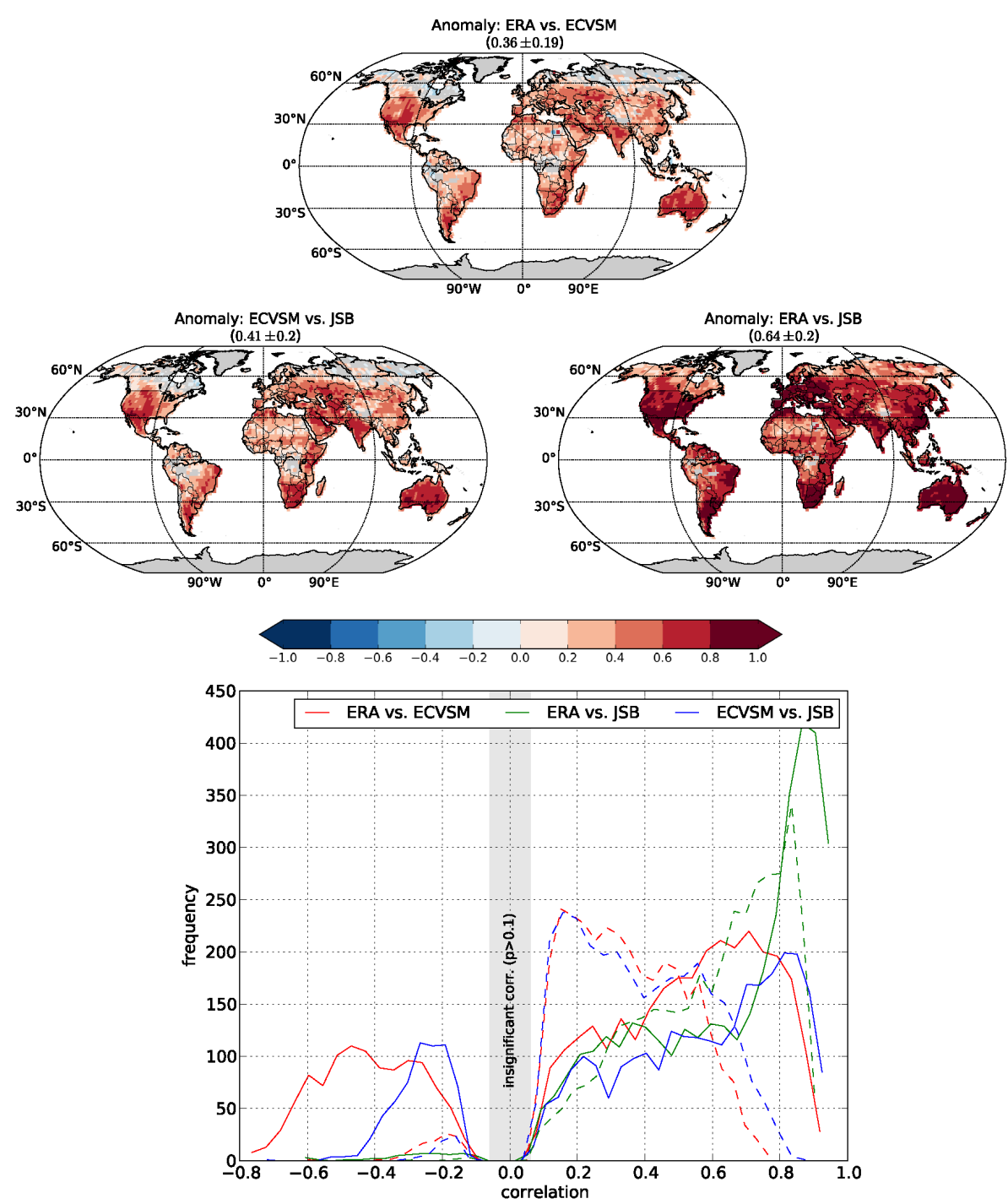

Fig. 4. Correlation coefficient for the linear correlation between the surface soil moisture anomalies: ERA vs. ECVSM, ECVSM vs. JSBACH, ERA vs. JSBACH. Only significant correlations ( $p$ value $<0.1$ ) are shown. Frequency distribution of correlation coefficients between different datasets is shown in the histogram (solid line: soil moisture data; dashed line: soil moisture anomalies).

shows the 5, 50 and $95 \%$ percentile maps for ECVSM, ERAinterim and JSBACH. The 5 and $95 \%$ values correspond to the lower (dry) and upper (wet) limits of the soil moisture dynamics. The similarity between the spatial patterns of each percentile was compared by calculating the correlation coefficient $\rho$ between the percentile maps of two datasets. Results of this correlation analysis are summarized in Fig. 5 for the different percentiles. The highest correlations $(\rho \approx 0.75)$ were found between ECVSM and JSBACH. The correlations between ERA-interim and JSBACH are lower $(\rho \approx 0.6)$ and the relationship between ERA-interim and ECVSM shows the weakest spatial correlations of the percentiles $(\rho \approx 0.4)$.

As JSBACH soil moisture and ECVSM soil moisture percentiles are completely independent, the results indicate that the model's soil moisture spatial pattern and temporal variability seems to be in good agreement with the observed soil moisture dynamics in ECVSM. ERA-interim deviates stronger from ECVSM observations, but is in closer agreement with JSBACH simulations. A potential reason for the different skills in reproducing the observed ECVSM soil moisture patterns by the models might be related to the precipitation forcing used. While the JSBACH experiments are based on offline simulations using the WFDEI, the ERAinterim precipitation results from coupled land-atmosphere simulations. ERA-interim precipitation biases have been reported in the literature. In particular, ERA-interim shows wet biases for the greater part of the Northern Hemisphere and in parts of South America (Dee et al., 2011). Note that the ERAinterim surface water balance is not necessarily closed as soil moisture nudging is conducted by the data assimilation 


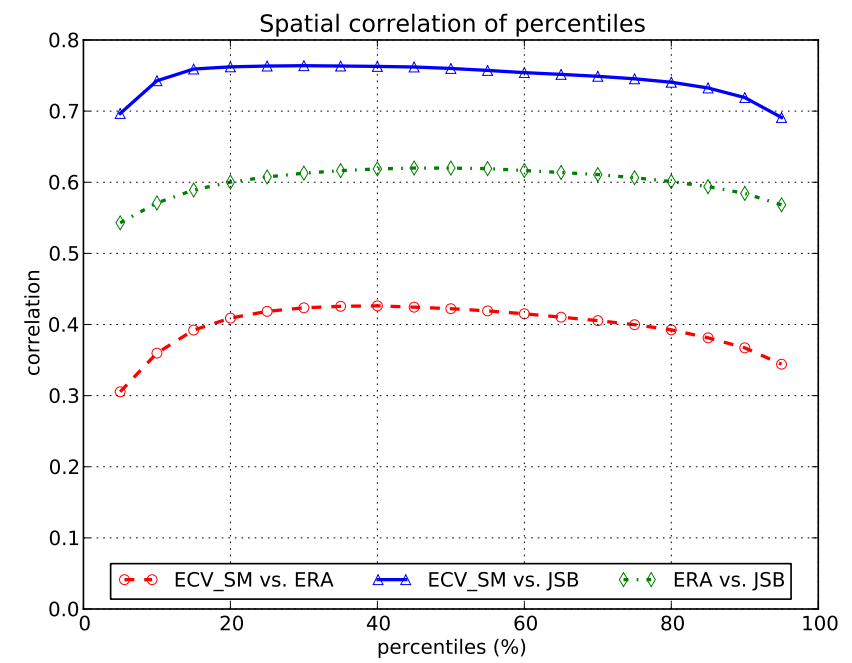

Fig. 5. Pearson product-moment correlation coefficients between the $p$-th percentiles of ERA-interim, JSBACH and ECVSM soil moisture fields.

system that may lead to sources and sinks in the surface water balance and, thus, to less consistency of soil moisture time series (Hagemann et al., 2005).

\subsubsection{Relationship of soil moisture and precipitation dynamics}

The relationship between precipitation and soil moisture dynamics was analyzed by comparing GPCP, ERA-interim and WFDEI monthly precipitation data with the surface soil moisture data, assuming that the precipitation dynamics is the major driver for the surface soil moisture dynamics on monthly timescales. The effect of evaporation is therefore not explicitly considered in the analysis, but the effect of evapotranspiration is however reflected in the soil moisture dynamics of ECVSM as well as the model-based soil moisture fields.

Figure 6 shows the correlation coefficients between monthly precipitation (rainfall and snowfall) and surface soil moisture anomalies. Both ERA-interim and JSBACH show high anomaly correlations with all precipitation datasets. The highest anomaly correlations are observed for ERA-interim with ERA-interim precipitation data and for JSBACH with WFDEI precipitation data, as would have been expected since these are the respective precipitation forcing datasets used for the generation of the soil moisture datasets. The anomaly correlation of ERA-interim with the ERA-interim precipitation data is highest $(\rho>0.8)$ in tropical areas. The correlation patterns of the soil moisture datasets with either GPCP or WFDEI precipitation are very similar for all soil moisture datasets. This is explained by the bias correction of GPCP and WFDEI, which is applied on monthly timescales using the same GPCC observations (see Sect. 2.2). The monthly mean (anomalies) are therefore correlated with each other.

The ECVSM soil moisture shows coherent anomaly correlation patterns with all precipitation datasets. In general, the correlations are lower than between the simulated soil moisture fields and precipitation data. However, significant positive correlations $(\rho \approx 0.3)$ between ECVSM and precipitation anomalies are found for the entire globe, which indicates a general skill of the ECVSM dataset in representing intra- and interannual soil moisture variability.

\subsubsection{Partial correlation results}

It has been demonstrated that the different soil moisture datasets show a significant correlation with different precipitation data as well as between each other. A correlation between simulated soil moisture and ECVSM might be however spurious as both might be dependent on common precipitation anomalies.

For model evaluation purposes it is however of particular interest whether the land surface model is capable of simulating the observed anomalies of a geophysical variable. This requires to remove the common forcing effects, precipitation in this case, in both soil moisture datasets.

The simulated soil moisture fields were therefore correlated against ECVSM using partial correlations where the effect of the precipitation forcing was removed (control variable). For ERA-interim, the ERA-interim precipitation was removed while WFDEI precipitation was removed for JS$\mathrm{BACH}$ simulations. As the true precipitation is unknown, the GPCP dataset is assumed to be the precipitation dataset that best captures the temporal and spatial precipitation dynamics of the ECVSM dataset. It is therefore used as a control variable on the ECVSM soil moisture fields for the partial correlation analysis. This approach allows one to deduct if the used dataset shows common soil moisture signals that are independent from the governing soil moisture dynamics. It is therefore an additional test to assess the similarities between the different investigated datasets.

Figure 7 shows partial correlation results that are based on soil moisture anomaly time series. The partial correlation coefficients of ERA-interim and JSBACH are very similar. Significant partial correlations between the simulated and observed soil moisture data are especially observed in semiarid regions. In general, JSBACH shows higher partial correlation coefficients for the soil moisture data than ERA-interim.

The highest partial correlation coefficients are observed in regions that are not affected by snow or by dense vegetation. These areas correspond to regions where the satellite observations are most sensitive to soil moisture variability and where the evapotranspiration is largely affected by soil moisture limitations. The largest differences between the partial correlation coefficients are observed in the Sahelian belt in Africa, where JSBACH has partial correlation coefficients 

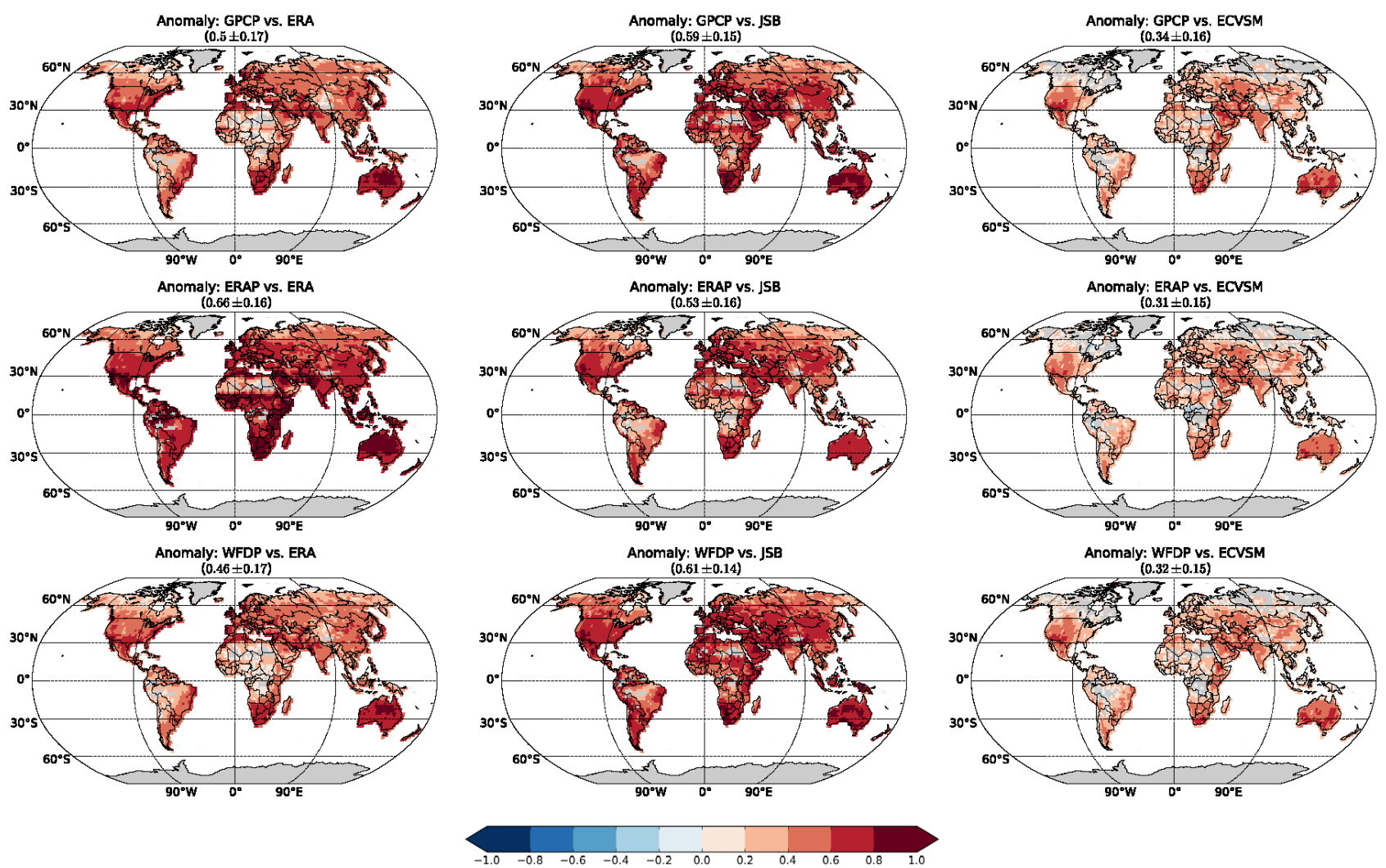

Fig. 6. Significant correlations ( $p$ value $<0.1$ ) of monthly GPCP (top panels), ERA-interim (middle panels) and WFDEI precipitation anomalies against ERA-interim (left panels), JSBACH (middle panels) and ECVSM (right panels) soil moisture anomalies.
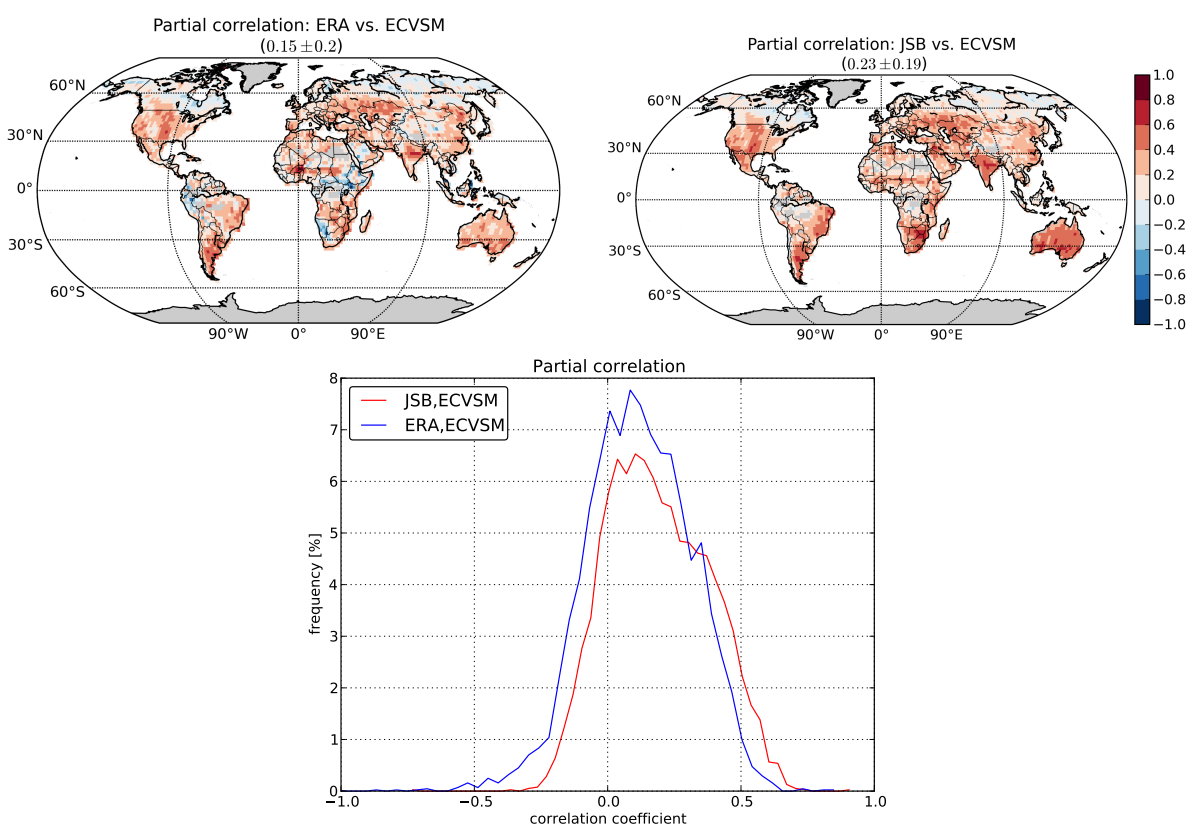

Fig. 7. Correlation coefficients of partial correlation between ERA-interim (left panel) and JSBACH (right panel) soil moisture anomalies against ECVSM soil moisture anomalies with removal of the effect of the respective precipitation forcing. 

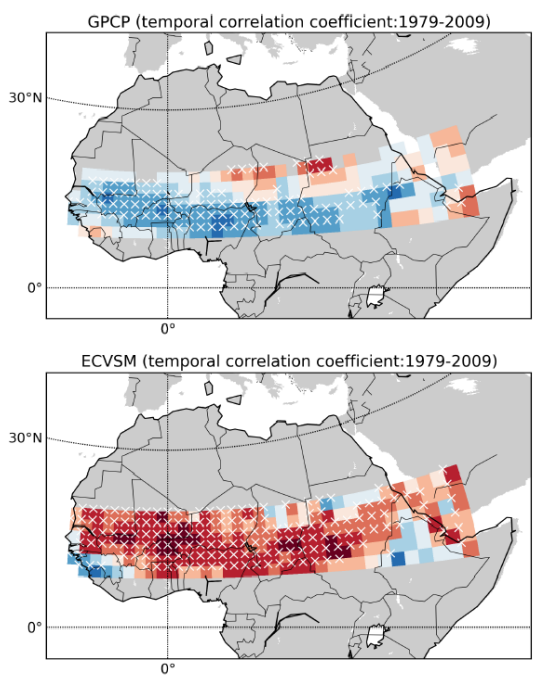
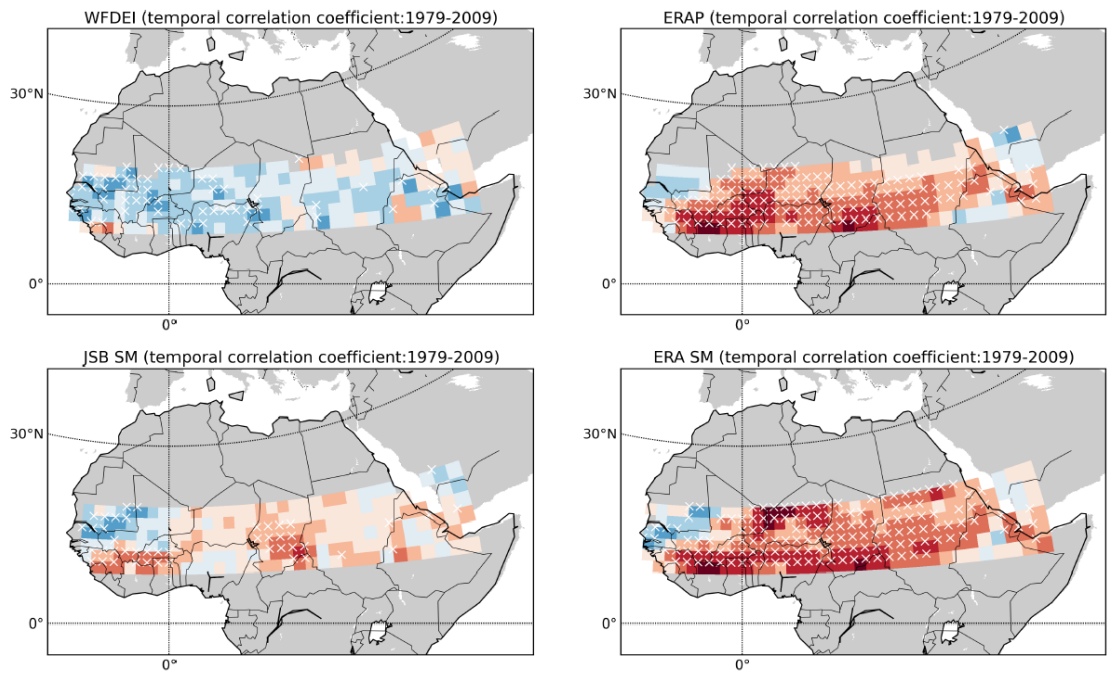

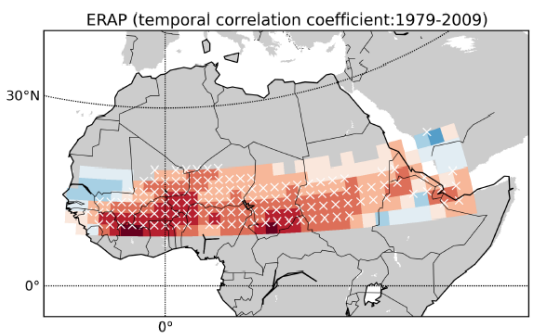

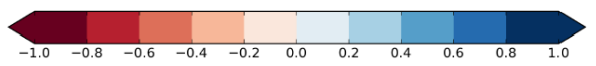

Fig. 8. Pearson product-moment coefficient for temporal trend of precipitation (top panels) and soil moisture (bottom panels) for the Sahelian rainfall seasons (June-September) in the period 1979-2009: precipitation (from left to right panels: GPCP, WFDEI, ERA-interim), soil moisture (from left to right panels: ECVSM, JSBACH, ERA-interim). Grid cells with significant correlations $(p$ value $<0.1)$ are indicated by stippled areas.

between 0.2 and 0.6, whereas ERA-interim does not show any correlation in this region.

The fact that both datasets show correlations between simulated and observed surface soil moisture after removal of the effect of precipitation is an indication that the ECVSM as well as the model simulations capture a similar intra- and interannual soil moisture variability, independent from rainfall. The partial correlation analysis might be therefore considered as a diagnostic for the similarity of ECVSM and model simulated interannual soil moisture dynamics.

\subsection{Sahelian drought and interannual soil moisture variability}

An increase in Sahelian vegetation and precipitation was observed since their minimum in the 1980s (Olsson et al., 2005; Ali and Lebel, 2009; Huber et al., 2011; Fensholt and Proud, 2012). Figure 8 shows linear trends of monthly mean precipitation and soil moisture for the period 1979-2009. A clear increase in precipitation in the Sahelian rainfall season (JJAS) is observed in the GPCP dataset, which is consistent with the literature. The WFDEI precipitation data shows also a positive precipitation trend, but the areas with a significant trend are smaller. On the contrary, ERA-interim shows a significant negative trend in the precipitation time series, which contradicts the in situ ground observations from GPCC that are included in both the WFDEI data as well as GPCP precipitation estimates. There is no obvious explanation why ERA-interim behaves different than the other two precipitation records. One reason might be that the usage of different observing systems in the data assimilation system used for the ERA re-analysis may lead to biases or spurious trends (Hagemann et al., 2005) and should therefore be interpreted very carefully.

The time series of spatially integrated precipitation in the Sahel shows a very similar temporal evolution with a positive trend for WFDEI and GPCP, whereas the long-term trend in precipitation is less significant in WFDEI than for GPCP (Fig. 9). The soil moisture in ERA-interim and ECVSM shows significant negative soil moisture trends in the Sahel, while the JSBACH simulations do not show any significant change over the investigated time period. It has been however shown by Loew (2013) that the significant positive trend in GPCP data is mainly caused by the strong negative precipitation anomalies at the beginning of the 1980s and is not significant in the years thereafter, and that the long-term trend is not significant if a few years in the 1980s are discarded from the analysis.

Dorigo et al. (2012a) found a significant negative trend of June-July-August surface soil moisture in the same region, as derived from the ECVSM dataset for the period 19882010. A comparison between reanalysis surface soil moisture trends and microwave surface soil moisture observations at the global scale is provided in Albergel et al. (2013). They compared two different reanalysis products (ERA-LAND and MERRA) against ECVSM. They found a significant negative soil moisture trend (drying) for $72 \%$ of the globe for ERA-Land while for MERRA re-analysis positive trends for $59 \%$ were found. The ECVSM shows significant negative 

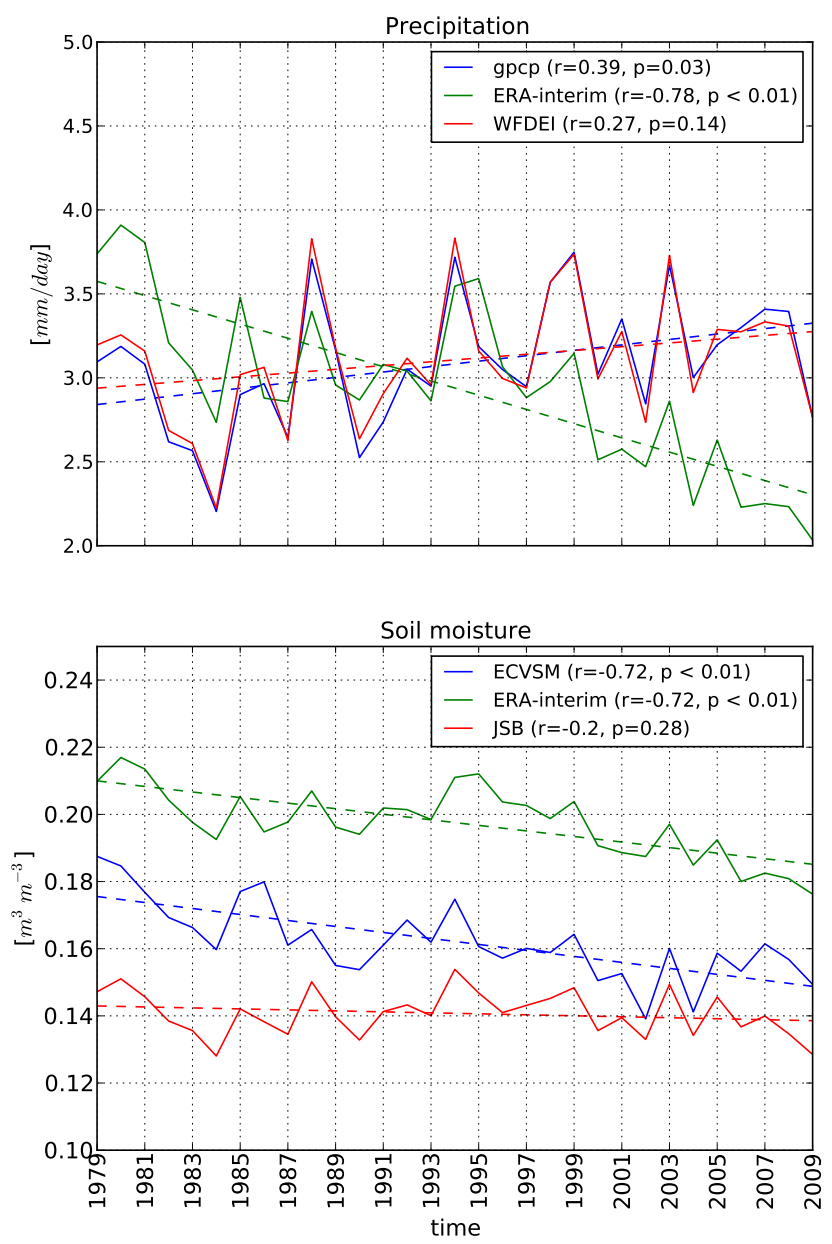

Fig. 9. Time series of mean Sahelian rainfall (top panel) and soil moisture (bottom panel) as aggregated over the area from 10 to $20^{\circ} \mathrm{N}$ and $20^{\circ} \mathrm{W}$ to $40^{\circ} \mathrm{E}$ for the different datasets used in the study.

trends for $73.2 \%$, which was found to be more in line with ERA-Land.

The ECVSM as well as the ERA-interim soil moisture show significant negative trends in wide parts of the Sahel (Fig. 8) while the JSBACH simulation shows a more diverse picture. In the central part a significant negative temporal trend is also observed, while a dipole of significant trends is observed in the western part with an increase in the north and a decrease in the south. The eastern part shows no significant trends in the JSBACH simulation. The positive trend in precipitation and negative trend in surface soil moisture seem to be contradictory, but could be related to an increase in evapotranspiration by the increased abundance of vegetation in the area.

In the following, we will investigate the interannual and decadal variability of surface soil moisture as observed by ECVSM and as simulated by ERA-interim and JSBACH. The analysis will focus exclusively on the anomalies of soil moisture and precipitation in order to be independent of biases between the different datasets.

The interannual soil moisture and precipitation anomalies for the Sahel $\left(20^{\circ} \mathrm{W}-45^{\circ} \mathrm{E}, 10-20^{\circ} \mathrm{N}\right)$ are shown in Fig. 10 in time-latitude diagrams. The ECVSM and especially ERAinterim surface soil moisture show a decline in the surface soil moisture content throughout the period and all latitudes, as has been already discussed, while the JSBACH soil moisture shows no clear temporal trend. The ERA-interim time series shows some discontinuities. A drier period (19831995 ) is followed abruptly by a wetter period that lasts until approximately 2001. A further drier period follows after 2006.

The precipitation anomalies between GPCP and WFDEI are consistent with each other as would have been expected, while ERA-interim precipitation shows a pronounced decline throughout the period 1979-2009.

The ERA-interim and ECVSM soil moisture anomalies show a linear temporal trend of soil moisture for the entire time period. Linear detrended anomaly time series were therefore used for the further analysis to focus the analysis exclusively on interannual soil moisture anomalies and to avoid any suspicious correlations due to common longterm trends. The ECVSM and JSBACH surface soil moisture show very consistent anomaly patterns with precipitation if the linear trends are removed from the data. In general the ECVSM data reproduces very well the dry and wet anomalies that are observed in the GPCP record.

To analyze the relationship between soil moisture and precipitation anomalies, the correlation between the anomaly time series was calculated for different regions (Fig. 1). The anomaly correlation coefficients between precipitation and soil moisture are summarized in Fig. 11. Very similar correlation coefficients are found for GPCP and WFDEI as both use the same in situ observations from GPCC on monthly timescales to compensate for biases in their data products. JSBACH soil moisture anomalies show high correlations $(r>0.6)$ for all precipitation datasets, while ERA-interim soil moisture anomalies are best correlated with ERA-interim precipitation data. The ECVSM anomalies show highest correlations with WFDEI/GPCP precipitation anomalies in all regions.

As the soil moisture anomalies are likely to be highly correlated with the precipitation anomalies, a partial correlation analysis was conducted to quantify how the ECVSM observations are related to the simulated surface soil moisture dynamics when the effect of the precipitation boundary condition is removed. It has been shown that the ERA-interim and ECV soil moisture both show a long-term decline of soil moisture in the analysis period. This common linear trend can introduce a significant correlation in the partial correlation analysis. The partial correlation was therefore conducted twice, once based on soil moisture and precipitation anomalies and second on anomalies that have been detrended prior to the analysis (Fig. 12). 

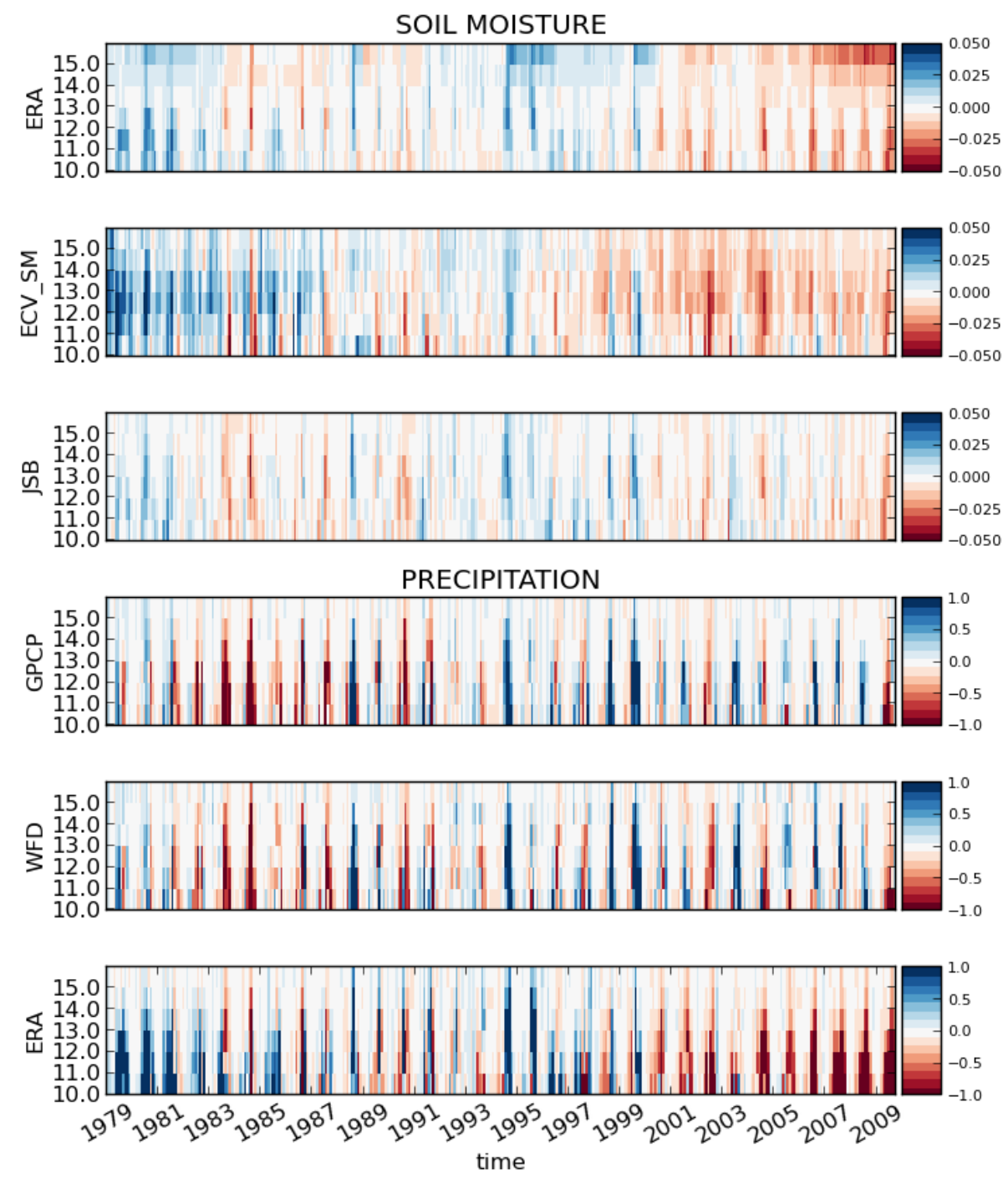

Fig. 10. Time-latitude diagrams for monthly anomalies of surface soil moisture $\left[\mathrm{m}^{3} \mathrm{~m}^{-3}\right]$ and precipitation $\left[\mathrm{mm}^{-1}{ }^{-1}\right]$ in the Sahel region $\left(20^{\circ} \mathrm{W}-45^{\circ} \mathrm{E}, 10-20^{\circ} \mathrm{N}\right)$. Anomalies are calculated by removing the mean seasonal climatology derived from the whole time series (19792009).

In all regions, the ERA-interim and JSBACH soil moisture anomalies show a positive correlation with the ECVSM anomalies. In the western Sahel (W1, W2), ERA-interim and JSBACH show these positive correlations with ECVSM also when the data was detrended before the analysis. Only JSBACH shows a positive correlation with the ECVSM soil moisture anomalies in the central and eastern Sahel when the linear trend in the time series has been removed. This clearly indicates that the partial correlation of ERA-interim anomalies is largely dependent on the long-term linear trend in the dataset and cannot be interpreted as a common interannual soil moisture dynamics with ECVSM. On the contrary, negative correlations between ERA-interim and ECVSM soil moisture are observed for the eastern and central regions, which indicates that the ERA-interim soil moisture dynamics is highly dependent on the ERA-interim precipitation data in these regions.

\section{Summary and conclusions}

The objectives of the present study were to assess the potential and limitations of the novel ECVSM dataset for climate modeling applications. The identified potentials and limitations are briefly summarized in Table 1 . The analysis in the present paper focused on a limited set of potential applications of ECVSM for climate model evaluation, the general study of soil moisture-precipitation interdependencies as well as on the applicability of ECVSM to capture interannual soil moisture dynamics and its anomalies at the regional scale. All analyses were done on monthly timescales. 

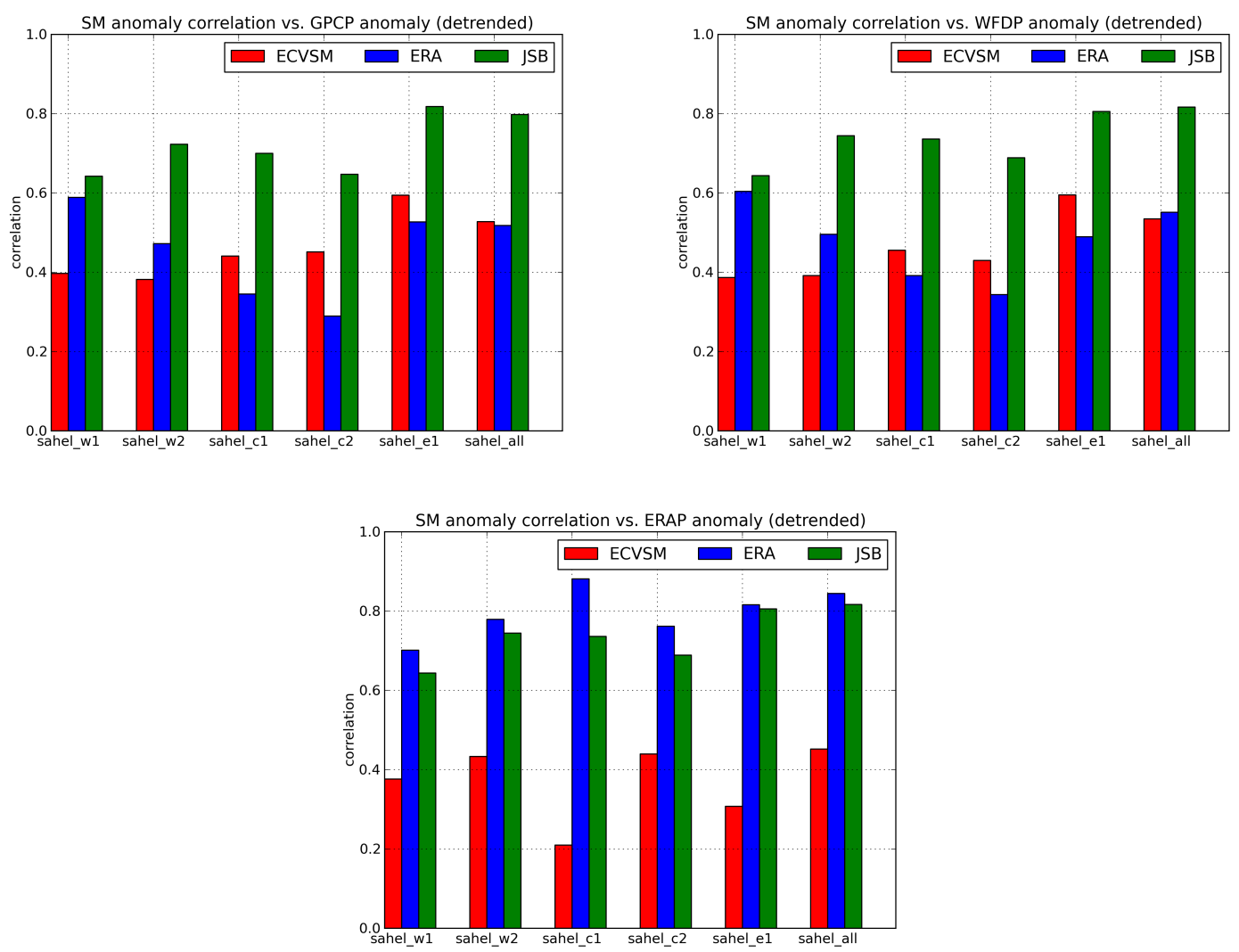

Fig. 11. Correlation coefficient between precipitation and soil moisture anomalies in different regions in the Sahel: GPCP (top left panel), WFD (top right panel) and ERA-interim precipitation (bottom panel). Data was detrended before analysis.

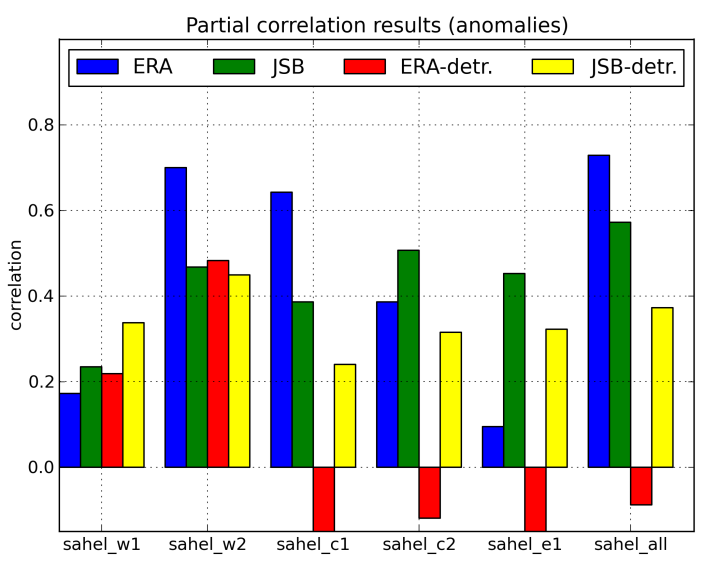

Fig. 12. Partial correlation coefficients between ERA-interim and JSBACH soil moisture and ECVSM with prior removal of precipitation influence on the correlation coefficient.
The ECVSM dataset is unique, as it is the first and only existing observation-based soil moisture data record for multiple decades. The analysis has shown that the present dataset is generally in good agreement with other soil moisture datasets from modeling studies as well as rainfall data.

In areas where the microwave signal is in general sensitive to soil moisture dynamics, the ECVSM dataset shows reasonable agreement with the ERA-interim and JSBACH soil moisture datasets for absolute values as well as for the soil moisture anomalies.

\section{Model evaluation using soil moisture statistics}

Using percentile distributions has been found to be a useful approach to evaluate the general spatial pattern of soil moisture of a land surface scheme used in a climate model as well as its temporal variability. The JSBACH soil moisture fields have shown higher spatial similarities to the ECVSM observations than the ERA-interim soil moisture field. These differences might be partly attributed to the differences in the precipitation forcing as is indicated by a partial correlation analysis, which revealed that the ECVSM soil moisture anomalies show comparable correlation patterns with ERAinterim and JSBACH soil moisture anomalies after removal of the influence of the precipitation forcing. It needs to be 
Table 1. Summary of potential and limitations of ECVSM for climate modeling applications.

\begin{tabular}{|c|c|}
\hline Potential & Current limitations \\
\hline \multicolumn{2}{|c|}{ Climate model evaluation } \\
\hline Percentile statistics are useful tool for model evaluation & $\begin{array}{l}\text { ECVSM soil moisture probability density } \\
\text { function is dependent on Noah GLDAS and } \\
\text { therefore does not provide a model independent } \\
\text { dataset for soil moisture percentile distribution }\end{array}$ \\
\hline \multirow[t]{2}{*}{$\begin{array}{l}\text { ECVSM shows consistent temporal trend patterns } \\
\text { with precipitation and ancillary soil moisture data }\end{array}$} & $\begin{array}{l}\text { ECVSM shows discontinuities in the long-term } \\
\text { time series, which are likely to be the result from } \\
\text { changing observing systems. Any conclusions } \\
\text { from trend analysis therefore need to be taken } \\
\text { very carefully. }\end{array}$ \\
\hline & $\begin{array}{l}\text { Time series not homogeneous due to different data } \\
\text { rescaling approaches before and after } 1988 \text {; see } \\
\text { Liu et al. }(2012) \text {, Sect. } 3.1 .2 \text { for details } \\
\text { Limited data coverage in early years }(<1990)\end{array}$ \\
\hline \multicolumn{2}{|c|}{ Process and regional studies } \\
\hline $\begin{array}{l}\text { Good representation of intra- and interannual soil } \\
\text { moisture anomalies at global to regional scale }\end{array}$ & $\begin{array}{l}\text { Risk of regionally missing soil moisture } \\
\text { information due to binary-like blending technique } \\
\text { applied; example: missing Europe's } 2003 \text { heat wave }\end{array}$ \\
\hline $\begin{array}{l}\text { Suitable soil moisture information for } \\
\text { land-atmosphere interactions in the Sahel }\end{array}$ & $\begin{array}{l}\text { High latitude limitation due to snow cover and } \\
\text { frozen soil conditions }\end{array}$ \\
\hline
\end{tabular}

noted however, that the ERA-interim soil moisture dataset does not benefit from recent improvements in the ECMWF land surface scheme. ERA-interim soil moisture might show different variability in different years. The ERA-land reanalysis has therefore been generated, which is an offline estimate of land surface fluxes without implicit coupling to an atmospheric model (Balsamo et al., 2012; Albergel et al., 2013).

While the percentile distribution is in general a very useful method to evaluate the general soil moisture dynamics of a model from observational data, it needs to be emphasized that the soil moisture dynamics in the ECVSM dataset is not purely observation based. The ECVSM final product was generated by harmonizing a multitude of soil moisture products using the Noah land surface model output from the Global Land Data Assimilation System (GLDAS) as a common scaling reference (Liu et al., 2011). This implies that the soil moisture statistics represented in ECVSM depends on the soil moisture dynamics of the Noah land surface model. ECVSM can therefore not provide an independent data source for the statistics of soil moisture dynamics at a particular location.

\section{Interannual soil moisture dynamics}

It is however emphasized that the temporal dynamic in the dataset is not affected by the normalization procedure. Thus, comparing temporal soil moisture and precipitation anomalies provides additional insight in the temporal soil moisture dynamics as represented by ECVSM. It was demonstrated in the present study that the ECVSM dataset shows in general good anomaly correlations with different global precipitation products. Additionally, the ECVSM dataset captures well the intra- and interannual soil moisture variability and has also skill to represent soil moisture dynamics independent from the precipitation forcing. The highest skill in representing soil moisture dynamics was observed in areas that are not affected by dense vegetation or snow and ice. As these areas could be clearly identified from the partial correlation analysis it can be concluded that partial correlation can be used as an indirect validation of the sensitivity of ECVSM to soil moisture variability.

\section{Data homogeneity}

In high latitudes, the data density of ECVSM is limited due to snow cover and frozen ground conditions. Negative correlations between ECVSM and simulated soil moisture were observed in these high latitudes, which are likely due to missing snowmelt peaks in the first part of the ECVSM time series. Further detailed studies on the reasons for these negative correlations are required.

The ECVSM shows discontinuities in its time series, which are especially recognized in zonal mean anomaly plots (Fig. 3). These temporal discontinuities are likely to be caused by a change in the observing system, which affects 

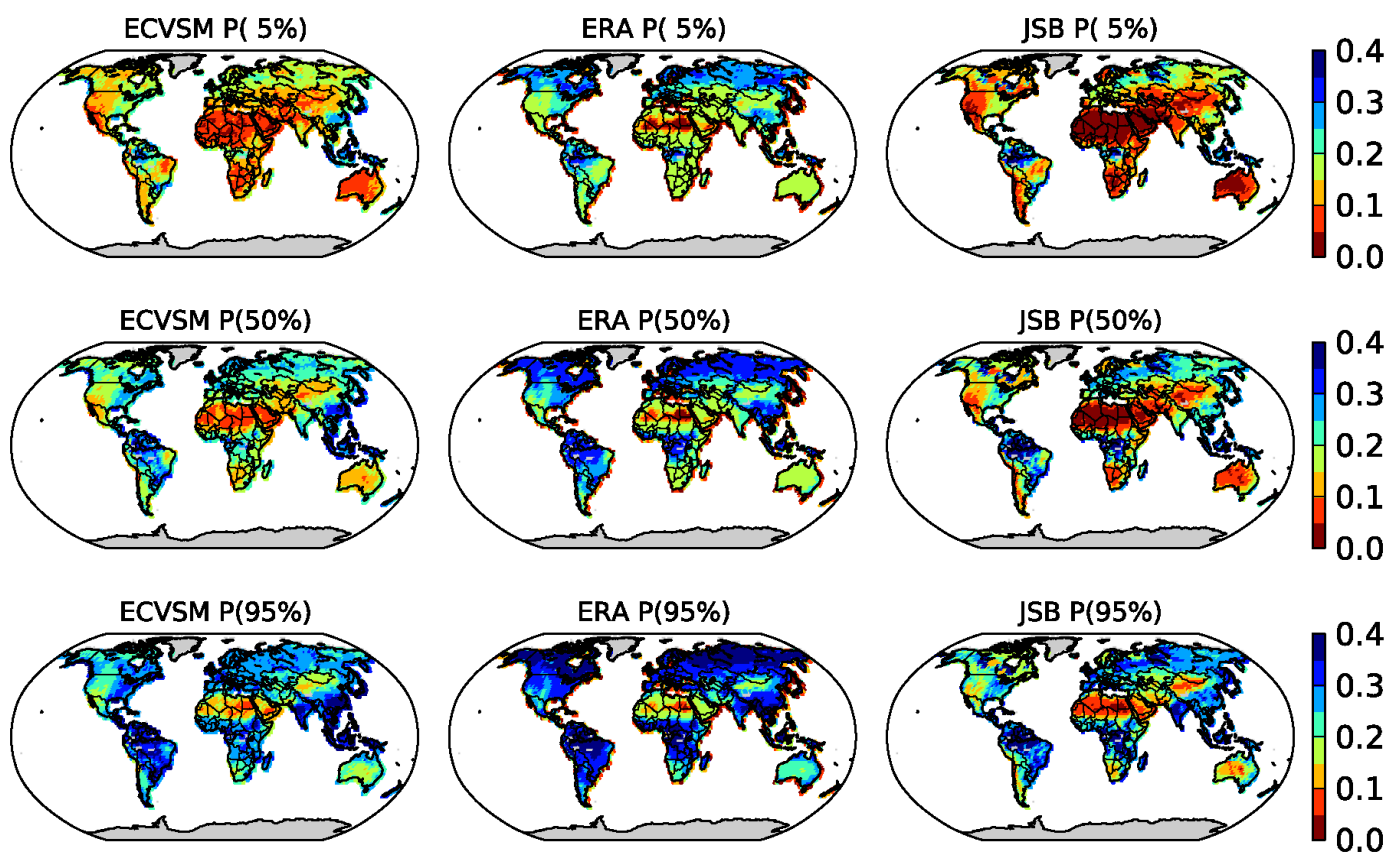

Fig. A1. Soil moisture percentiles $\left[\mathrm{m}^{3} \mathrm{~m}^{-3}\right.$ ] for ECVSM (left panels), ERA-interim (middle panels) and JSBACH (right panels) for three different percentiles of $p=(0.05,0.5,0.95)$ (top-down panels).

the absolute soil moisture values as well as the temporal sampling of the data. Discontinuities are, e.g., observed in 2002 (integration of AMSR-E data), 1987 (change from SMM/R to SSM/I) and 2006 (inclusion of METOP ASCAT). The input data for ECVSM has been also rescaled prior to the generation of the long-term record. Different data rescaling was applied before and after 1987 for the passive microwave observations (see Liu et al., 2012, Sect. 3.1.2 for details). As a consequence of this scaling, some long-term trends in the time series might be minimized and any trend analysis performed on ECVSM needs to be interpreted critically. Dorigo et al. (2012a) therefore investigated global trends in surface soil moisture dynamics only after 1988. Loew (2013) has analyzed the importance of different periods on the estimation of long-term trends from satellite ECV records and shows that small changes in the investigation period might have a strong effect on the correlation results obtained. We therefore investigated the robustness of the results of the present study by comparing the results obtained from the whole data record (1979-2009) against results for the period 1987-2009. In general, results (not shown in the paper) from both periods show very similar spatial correlation patterns with slightly higher correlation values for the period 1987-2009, which would have been expected as discussed before.

\section{Regional climate studies - the Sahel example}

It has been shown that the ECVSM dataset is well suited to study regional climate phenomena on multidecadal timescales. The Sahelian rainfall dynamics and its representation in ECVSM were investigated as an example for the potential applications of ECVSM on the regional scale. ECVSM has high correlations of surface soil moisture anomalies with the soil moisture anomalies of JSBACH as well as with observed precipitation anomalies. Partial correlation analysis revealed the highest partial correlation coefficients between ECVSM and JSBACH, which indicates that both datasets show a comparable soil moisture residual after removal of the precipitation dynamics. It needs to be emphasized that the temporal dynamics of ECVSM and JSBACH is completely independent as both are based on different data sources. Significant correlations between the datasets can therefore be considered as a common representation of soil moisture dynamics. ECVSM therefore provides suitable information to support regional climate studies in the Sahel. More detailed studies are however needed to better understand the different drivers of soil moisture dynamics in this region.

Overall, the ECVSM dataset provides a first unique dataset with relevant information for climate studies. A further potential application of ECVSM for climate model evaluation studies is the identification of characteristic timescales in land surface models. By calculating the autocorrelation length from both, models and observations, one can identify characteristic timescales. This information might be used, e.g., to infer relevant model specific soil parameterizations like characteristic timescales, which are important for having a realistic soil moisture memory effect in the climate model 
land surface schemes, which is in turn of particular importance for seasonal climate predictions. Further studies will therefore focus on an evaluation of soil moisture memory effects from ECVSM and comparisons to the MPI-ESM land surface scheme.

Acknowledgements. This work was supported through the Cluster of Excellence CliSAP (EXC177), University of Hamburg, funded through the German Science Foundation (DFG) and the ESA Climate Change Initative Climate Modelling User Group (contract: 4000100222/10/I-AM). Tobias Stacke acknowledges funding from the Federal Ministry of Education and Research in Germany (BMBF) through the research programme MiKlip (FKZ: 01LP1108A) and Wouter Dorigo and Richard de Jeu are partly sponsored through ESA's Climate Change Initiative for Soil Moisture (contract: 4000104814/11/I-NB). The WFDEI dataset was generated and provided through the EU FP6 WATCH project (contract number 036946). The GPCP combined precipitation data were provided by the NASA/Goddard Space Flight Center's Laboratory for Atmospheres, which develops and computes the dataset as a contribution to the GEWEX Global Precipitation Climatology Project.

The service charges for this open access publication have been covered by the Max Planck Society.

Edited by: N. Romano

\section{References}

Adler, R. F., Huffman, G. J., Chang, A., Ferraro, R., Xie, P.-P., Janowiak, J., Rudolf, B., Schneider, U., Curtis, S., Bolvin, D., Gruber, A., Susskind, J., Arkin, P., and Nelkin, E.: The Version-2 Global Precipitation Climatology Project (GPCP) Monthly Precipitation Analysis (1979-Present), J. Hydrometeorol., 4, 11471167, 2003.

Adler, R. F., Gu, G., and Huffman, G. J.: Estimating Climatological Bias Errors for the Global Precipitation Climatology Project (GPCP), J. Appl. Meteorol. Clim., 51, 84-99, 2011.

Albergel, C., de Rosnay, P., Gruhier, C., Muñoz Sabater, J., Hasenauer, S., Isaksen, L., Kerr, Y., and Wagner, W.: Evaluation of remotely sensed and modelled soil moisture products using global ground-based in situ observations, Remote Sens. Environ., 118, 215-226, 2012.

Albergel, C., Dorigo, W., Reichle, R. H., Balsamo, G., de Rosnay, P., Muñoz Sabater, J., Isaksen, L., de Jeu, R., and Wagner, W.: Skill and global trend analysis of soil moisture from reanalyses and microwave remote sensing, J. Hydrometeorol., 14, 12591277, doi:10.1175/JHM-D-12-0161.1, 2013.

Ali, A. and Lebel, T.: The Sahelian standardized rainfall index revisited, Int. J. Climatol., 29, 1705-1714, 2009.

Balsamo, G., Albergel, C., Beljaars, A., Boussetta, S., Brun, E., Cloke, H., Dee, D., Dutra, E., Pappenberger, F., de Rosnay, P., Sabater, J. M. N., Stockdale, T., and Vitart, F.: ERAInterim/Land: A global land-surface reanalysis based on ERAInterim meteorological forcing, ERA Report Series, ECMWF, Shinfield Park, Reading, 2012.
Bartalis, Z., Wagner, W., Naeimi, V., Hasenauer, S., Scipal, K., Bonekamp, H., Figa, J., and Anderson, C.: Initial soil moisture retrievals from the METOP-A Advanced Scatterometer (ASCAT), Geophys. Res. Let., 34, L20401, doi:10.1029/2007GL031088, 2007.

Beck, H. E., de Jeu, R. A. M., Schellekens, J., van Dijk, A. I. J. M., and Bruijnzeel, L. A.: Improving Curve Number Based Storm Runoff Estimates Using Soil Moisture Proxies, IEEE J. Select. Top. Appl. Earth Observ. Remote S., 2, 250-259, 2009.

Bisselink, B., van Meijgaard, E., Dolman, A. J., and de Jeu, R. A. M.: Initializing a regional climate model with satellitederived soil moisture, J. Geophys. Res., 116, D02121, doi:10.1029/2010JD014534, 2011.

Brocca, L., Hasenauer, S., Lacava, T., Melone, F., Moramarco, T., Wagner, W., Dorigo, W., Matgen, P., Martínez-Fernández, J., Llorens, P., Latron, J., Martin, C., and Bittelli, M.: Soil moisture estimation through ASCAT and AMSR-E sensors: An intercomparison and validation study across Europe, Remote Sens. Environ., 115, 3390-3408, 2011.

Brocca, L., Moramarco, T., Melone, F., Wagner, W., Hasenauer, S., and Hahn, S.: Assimilation of Surface- and Root-Zone ASCAT Soil Moisture Products Into Rainfall-Runoff Modeling, IEEE T. Geosci. Remote, 50, 2542-2555, 2012.

Brovkin, V., Raddatz, T., Reick, C. H., Claussen, M., and Gayler, V.: Global biogeophysical interactions between forest and climate, Geophys. Res. Let., 36, L07405, doi:10.1029/2009GL037543, 2009.

Brovkin, V., Boysen, L., Raddatz, T., Gayler, V., Loew, A., and Claussen, M.: Evaluation of vegetation cover and land-surface albedo in MPI-ESM CMIP5 simulations, J. Adv. Model. Earth Syst., 5, 48-57, 2013.

Charney, J., Quirk, W. J., Chow, S., and Kornfield, J.: A Comparative Study of the Effects of Albedo Change on Drought in SemiArid Regions, J. Atmos. Sci., 34, 1366-1385, 1977.

Crow, W. T., Berg, A. A., Cosh, M. H., Loew, A., Mohanty, B. P., Panciera, R., de Rosnay, P., Ryu, D., and Walker, J. P.: Upscaling sparse ground-based soil moisture observations for the validation of coarse-resolution satellite soil moisture products, Rev. Geophys., 50, 1-20, 2012.

Dee, D. P., Uppala, S. M., Simmons, A. J., Berrisford, P., Poli, P., Kobayashi, S., Andrae, U., Balmaseda, M. A., Balsamo, G., Bauer, P., Bechtold, P., Beljaars, A. C. M., van de Berg, L., Bidlot, J., Bormann, N., Delsol, C., Dragani, R., Fuentes, M., Geer, A. J., Haimberger, L., Healy, S. B., Hersbach, H., Hólm, E. V., Isaksen, L., Kållberg, P., Köhler, M., Matricardi, M., McNally, A. P., Monge-Sanz, B. M., Morcrette, J.-J., Park, B.-K., Peubey, C., de Rosnay, P., Tavolato, C., Thépaut, J.-N., and Vitart, F.: The ERA-Interim reanalysis: configuration and performance of the data assimilation system, Q. J. Roy. Meteorol. Soc., 137, 553597, 2011.

de Jeu, R. A., Dorigo, W., Parinussa, R. M., Wagner, W., and Chung, D.: State of the Climate in 2011, B. Am. Meteorol. Soc., 93, S30S34, 2012.

Dharssi, I., Bovis, K. J., Macpherson, B., and Jones, C. P.: Operational assimilation of ASCAT surface soil wetness at the Met Office, Hydrol. Earth Syst. Sci., 15, 2729-2746, doi:10.5194/hess15-2729-2011, 2011. 
Dorigo, W. A., de Jeu, R., Chung, D., Parinussa, R., Liu, Y., Wagner, W., and Fernández-Prieto, D.: Evaluating global trends (1988-2010) in harmonized multi-satellite surface soil moisture, Geophys. Res. Let., 39, L18405, doi:10.1029/2012GL052988, 2012a.

Dorigo, W. A., Gruber, A., de Jeu, R. A., Wagner, W., Stacke, T., Loew, A., Albergel, C., Brocca, L., Chung, D., Parinussa, R., and Kidd, R.: Evaluation of the ESA CCI soil moisture product using ground-based observations, Remote Sens. Environ., in press, 2012b.

Dorigo, W. A., Xaver, A., Vreugdenhil, M., Gruber, A., Hegyiová, A., Sanchis-Dufau, A., Zamojski, D., Cordes, C., Wagner, W., and Drusch, M.: Global Automated Quality Control of In Situ Soil Moisture Data from the International Soil Moisture Network, Vadose Zone J., 12, 1539-1663, doi:10.2136/vzj2012.00972013.

Dorigo, W. A., Scipal, K., Parinussa, R. M., Liu, Y. Y., Wagner, W., de Jeu, R. A. M., and Naeimi, V.: Error characterisation of global active and passive microwave soil moisture datasets, Hydrol. Earth Syst. Sci., 14, 2605-2616, doi:10.5194/hess-14-26052010, 2010.

Dorigo, W. A., Wagner, W., Hohensinn, R., Hahn, S., Paulik, C., Xaver, A., Gruber, A., Drusch, M., Mecklenburg, S., van Oevelen, P., Robock, A., and Jackson, T.: The International Soil Moisture Network: a data hosting facility for global in situ soil moisture measurements, Hydrol. Earth Syst. Sci., 15, 1675-1698, doi:10.5194/hess-15-1675-2011, 2011.

Draper, C. S., Walker, J. P., Steinle, P. J., de Jeu, R. A., and Holmes, T. R.: An evaluation of AMSR-E derived soil moisture over Australia, Remote Sens. Environ., 113, 703-710, 2009.

Draper, C. S., Reichle, R. H., De Lannoy, G. J. M., and Liu, Q.: Assimilation of passive and active microwave soil moisture retrievals, Geophys. Res. Lett., 39, L04401, doi:10.1029/2011GL050655, 2012.

Drusch, M.: Initializing numerical weather prediction models with satellite-derived surface soil moisture: Data assimilation experiments with ECMWF's Integrated Forecast System and the TMI soil moisture data set, J. Geophys. Res., 112, D03102, doi:10.1029/2006JD007478, 2007.

Fensholt, R. and Proud, S. R.: Evaluation of Earth Observation based global long term vegetation trends - Comparing GIMMS and MODIS global NDVI time series, Remote Sens. Environ., 119, 131-147, 2012.

Fensholt, R., Langanke, T., Rasmussen, K., Reenberg, A., Prince, S. D., Tucker, C., Scholes, R. J., Le, Q. B., Bondeau, A., Eastman, R., Epstein, H., Gaughan, A. E., Hellden, U., Mbow, C., Olsson, L., Paruelo, J., Schweitzer, C., Seaquist, J., and Wessels, K.: Greenness in semi-arid areas across the globe 1981-2007 an Earth Observing Satellite based analysis of trends and drivers, Remote Sens. Environ., 121, 144-158, 2012.

Fischer, E. M., Seneviratne, S. I., Vidale, P. L., Lüthi, D., and Schär, C.: Soil Moisture-Atmosphere Interactions during the 2003 European Summer Heat Wave, J. Climate, 20, 5081-5099, 2007.

Gruhier, C., de Rosnay, P., Hasenauer, S., Holmes, T., de Jeu, R., Kerr, Y., Mougin, E., Njoku, E., Timouk, F., Wagner, W., and Zribi, M.: Soil moisture active and passive microwave products: intercomparison and evaluation over a Sahelian site, Hydrol. Earth Syst. Sci., 14, 141-156, doi:10.5194/hess-14-1412010, 2010.
Hagemann, S., Arpe, K., and Bengtsson, L.: Validation of the hydrological cycle of ERA40, Tech. rep., ECMWF ERA-40 Proj. Rep. Ser. 24, ECMWF, Reading, UK, 2005.

Hagemann, S., Loew, A., and Andersson, A.: Combined evaluation of MPI-ESM land surface water and energy fluxes, J. Adv. Model. Earth Syst., 5, 259-286, doi:10.1029/2012MS000173, 2013.

Hickler, T., Eklundh, L., Seaquist, J. W., Smith, B., Ardö, J., Olsson, L., Sykes, M. T., and Sjöström, M.: Precipitation controls Sahel greening trend, Geophys. Res. Lett., 32, L21415, doi:10.1029/2005GL024370, 2005.

Huber, S. and Fensholt, R.: Analysis of teleconnections between AVHRR-based sea surface temperature and vegetation productivity in the semi-arid Sahel, Remote Sens. Environ., 115, 32763285, 2011.

Huber, S., Fensholt, R., and Rasmussen, K.: Water availability as the driver of vegetation dynamics in the African Sahel from 1982 to 2007, Global Planet. Change, 76, 186-195, 2011.

Jeu, R. A. M., Wagner, W., Holmes, T. R. H., Dolman, A. J., Giesen, N. C., and Friesen, J.: Global Soil Moisture Patterns Observed by Space Borne Microwave Radiometers and Scatterometers, Surv. Geophys., 29, 399-420, 2008.

Kerr, Y. H., Waldteufel, P., Wigneron, J.-P., Delwart, S., Cabot, F., Boutin, J., Escorihuela, M.-J., Font, J., Reul, N., Gruhier, C., Juglea, S. E., Drinkwater, M. R., Hahne, A., Martin-Neira, M., and Mecklenburg, S.: The SMOS Mission: New Tool for Monitoring Key Elements ofthe Global Water Cycle, Proc. IEEE, 98, 666687, 2010.

Koster, R. D., Dirmeyer, P. A., Guo, Z., Bonan, G., Chan, E., Cox, P., Gordon, C. T., Kanae, S., Kowalczyk, E., Lawrence, D., Liu, P., Lu, C.-H., Malyshev, S., McAvaney, B., Mitchell, K., Mocko, D., Oki, T., Oleson, K., Pitman, A., Sud, Y. C., Taylor, C. M., Verseghy, D., Vasic, R., Xue, Y., and Yamada, T.: Regions of strong coupling between soil moisture and precipitation, Science, 305, 1138-1140, 2004.

Lebel, T. and Ali, A.: Recent trends in the Central and Western Sahel rainfall regime (1990-2007), J. Hydrol., 375, 52-64, 2009.

Li, L., Gaiser, P. W., Bevilacqua, R. M., Jackson, T. J., Njoku, E. G., Rudiger, C., Calvet, J.-C., and Bindlish, R.: WindSat Global Soil Moisture Retrieval and Validation, IEEE T. Geosci. Remote, 48, 2224-2241, 2010.

Liu, Y. Y., Parinussa, R. M., Dorigo, W. A., De Jeu, R. A. M., Wagner, W., van Dijk, A. I. J. M., McCabe, M. F., and Evans, J. P.: Developing an improved soil moisture dataset by blending passive and active microwave satellite-based retrievals, Hydrol. Earth Syst. Sci., 15, 425-436, doi:10.5194/hess-15-425-2011, 2011.

Liu, Y. Y., Dorigo, W., Parinussa, R., de Jeu, R., Wagner, W., McCabe, M., Evans, J., and van Dijk, A.: Trend-preserving blending of passive and active microwave soil moisture retrievals, Remote Sens. Environ., 123, 280-297, 2012.

Loew, A.: Impact of surface heterogeneity on surface soil moisture retrievals from passive microwave data at the regional scale: The Upper Danube case, Remote Sens. Environ., 112, 231-248, 2008.

Loew, A.: Terrestrial satellite climate data records: how long is long enough - a test case for the Sahel, Theor. Appl. Climatol., doi:10.1007/s00704-013-0880-6, in press, 2013. 
Loew, A. and Govaerts, Y.: Towards Multidecadal Consistent Meteosat Surface Albedo Time Series, Remote Sens., 2, 957-967, 2010.

Loew, A., Ludwig, R., and Mauser, W.: Derivation of surface soil moisture from ENVISAT ASAR wide swath and image mode data in agricultural areas, IEEE T. Geosci. Remote, 44, 889-899, 2006.

Loew, A., Holmes, T., and de Jeu, R.: The European heat wave 2003: Early indicators from multisensoral microwave remote sensing?, J. Geophys. Res., 114, 1-14, 2009.

Lorenz, C. and Kunstmann, H.: The Hydrological Cycle in Three State-of-the-Art Reanalyses: Intercomparison and Performance Analysis, J. Hydrometeorol., 13, 1397-1420, 2012.

Mecklenburg, S., Drusch, M., Kerr, Y. H., Font, J., Martin-Neira, M., Delwart, S., Buenadicha, G., Reul, N., Daganzo-Eusebio, E., Oliva, R., and Crapolicchio, R.: ESA's Soil Moisture and Ocean Salinity Mission: Mission Performance and Operations, IEEE T. Geosci. Remote, 50, 1354-1366, 2012.

Miralles, D. G., van den Berg, M. J., Teuling, A. J., and de Jeu, R. A. M.: Soil moisture-temperature coupling: A multiscale observational analysis, Geophys. Res. Lett., 39, L21707, doi:10.1029/2012GL053703, 2012.

Mitchell, T. D. and Jones, P. D.: An improved method of constructing a database of monthly climate observations and associated high-resolution grids, Int. J. Climatol., 25, 693-712, 2005.

Mueller, B. and Seneviratne, S. I.: Hot days induced by precipitation deficits at the global scale, P. Natl. Acad. Sci. USA, 109, 1239812403, 2012.

Naeimi, V., Scipal, K., Bartalis, Z., Hasenauer, S., and Wagner, W.: An Improved Soil Moisture Retrieval Algorithm for ERS and METOP Scatterometer Observations, IEEE T. Geosci. Remote, 47, 1999-2013, 2009.

New, M., Hulme, M., and Jones, P.: Representing TwentiethCentury Space-Time Climate Variability, Part I: Development of a 1961-90 Mean Monthly Terrestrial Climatology, J. Climate, 12, 829-856, 1999.

New, M., Hulme, M., and Jones, P.: Representing TwentiethCentury Space-Time Climate Variability, Part II: Development of 1901-96 Monthly Grids of Terrestrial Surface Climate, J. Climate, 13, 2217-2238, 2000.

Njoku, E., Jackson, T., Lakshmi, V., Chan, T., and Nghiem, S.: Soil moisture retrieval from AMSR-E, IEEE T. Geosci. Remote, 41, 215-229, 2003.

Olsson, L., Eklundh, L., and Ardö, J.: A recent greening of the Sahel - trends, patterns and potential causes, J. Arid Environ., 63, 556$566,2005$.

Owe, M., de Jeu, R., and Holmes, T.: Multisensor historical climatology of satellite-derived global land surface moisture, J. Geophys. Res., 113, F01002, doi:10.1029/2007JF000769, 2008.

Parinussa, R. M., Meesters, A. G. C. A., Liu, Y. Y., Dorigo, W., Wagner, W., and de Jeu, R. A. M.: Error Estimates for Near-RealTime Satellite Soil Moisture as Derived From the Land Parameter Retrieval Model, IEEE Geosci. Remote S. Lett., 8, 779-783, 2011.

Parinussa, R. M., Holmes, T. R. H., and de Jeu, R. A. M.: Soil Moisture Retrievals From the WindSat Spaceborne Polarimetric Microwave Radiometer, IEEE T. Geosci. Remote, 50, 2683-2694, 2012.
Raddatz, T. J., Reick, C. H., Knorr, W., Kattge, J., Roeckner, E., Schnur, R., Schnitzler, K.-G., Wetzel, P., and Jungclaus, J.: Will the tropical land biosphere dominate the climate-carbon cycle feedback during the twenty-first century?, Clim. Dynam., 29, 565-574, 2007.

Reick, C., Raddatz, T., Brovkin, V., and Gayler, V.: The representation of natural and anthropogenic land cover change in MPIESM, J. Adv. Model. Earth Syst., doi:10.1002/jame.20022, in press, 2013.

Robock, A., Vinnikov, K. Y., Srinivasan, G., Entin, J. K., Hollinger, S. E., Speranskaya, N. A., Liu, S., and Namkhai, A.: The Global Soil Moisture Data Bank, B. Am. Meteorol. Soc., 81, 12811299, 2000.

Schneider, U., Fuchs, T., Meyer-Christoffer, A., and Rudolf, B.: Global Precipitation Analysis Products of the GPCC, Tech. Rep. July, Deutscher Wetterdienst, Offenbach, Germany, 2008.

Schumann, G., Lunt, D. J., Valdes, P. J., de Jeu, R. A. M., Scipal, K., and Bates, P. D.: Assessment of soil moisture fields from imperfect climate models with uncertain satellite observations, Hydrol. Earth Syst. Sci., 13, 1545-1553, doi:10.5194/hess-13-15452009, 2009.

Seneviratne, S. I. and Stöckli, R.: The Role of Land-Atmosphere Interactions, in: Climate Variability and Extremes during the Past 100 years, edited by: Brönnimann, S., Luterbacher, J., Ewen, T., Diaz, H. F., Stolarski, R. S., and Neu, U., Springer, 2008.

Seneviratne, S. I., Corti, T., Davin, E. L., Hirschi, M., Jaeger, E. B., Lehner, I., Orlowsky, B., and Teuling, A. J.: Investigating soil moisture-climate interactions in a changing climate: A review, Earth-Sci. Rev., 99, 125-161, 2010.

Stevens, B., Crueger, T., and Esch, M.: The Atmospheric Component of the MPI-M Earth System Model: ECHAM6, J. Adv Model. Earth Syst., 5, 146-172, doi:10.1002/jame.20015, 2013.

Su, Z., Dorigo, W., Fernández-Prieto, D., Van Helvoirt, M., Hungershoefer, K., de Jeu, R., Parinussa, R., Timmermans, J., Roebeling, R., Schröder, M., Schulz, J., Van der Tol, C., Stammes, P., Wagner, W., Wang, L., Wang, P., and Wolters, E.: Earth observation Water Cycle Multi-Mission Observation Strategy (WACMOS), Hydrol. Earth Syst. Sci. Discuss., 7, 7899-7956, doi:10.5194/hessd-7-7899-2010, 2010.

Taylor, C. M., Gounou, A., Guichard, F., Harris, P. P., Ellis, R. J., Couvreux, F., and De Kauwe, M.: Frequency of Sahelian storm initiation enhanced over mesoscale soil-moisture patterns, Nat. Geosci., 4, 430-433, 2011.

Taylor, C. M., de Jeu, R. A. M., Guichard, F., Harris, P. P., and Dorigo, W. A.: Afternoon rain more likely over drier soils, Nature, 489, 423-426, 2012a.

Taylor, K. E., Stouffer, R. J., and Meehl, G. A.: An Overview of CMIP5 and the Experiment Design, B. Am. Meteorol. Soc., 93, 485-498, 2012b.

Tramblay, Y., Bouaicha, R., Brocca, L., Dorigo, W., Bouvier, C., Camici, S., and Servat, E.: Estimation of antecedent wetness conditions for flood modelling in northern Morocco, Hydrol. Earth Syst. Sci., 16, 4375-4386, doi:10.5194/hess-16-43752012, 2012.

Uppala, S. M., Kallberg, P. W., Simmons, A. J., Andrae, U., Bechtold, V. D. C., Fiorino, M., Gibson, J. K., Haseler, J., Hernandez, A., Kelly, G. A., Li, X., Onogi, K., Saarinen, S., Sokka, N., Allan, R. P., Andersson, E., Arpe, K., Balmaseda, M. A., Beljaars, 
A. C. M., Berg, L. V. D., Bidlot, J., Bormann, N., Caires, S., Chevallier, F., Dethof, A., Dragosavac, M., Fisher, M., Fuentes, M., Hagemann, S., Holm, E., Hoskins, B. J., Isaksen, L., Janssen, P. A. E. M., Jenne, R., Mcnally, A. P., Mahfouf, J.-F., Morcrette, J.-J., Rayner, N. A., Saunders, R. W., Simon, P., Sterl, A., Trenberth, K. E., Untch, A., Vasiljevic, D., Viterbo, P., and Woollen, J.: The ERA-40 re-analysis, Q. J. Roy. Meteorol. Soc., 131, 2961-3012, 2005.

Wagner, W., Lemoine, G., and Rott, H.: A Method for Estimating Soil Moisture from ERS Scatterometer and Soil Data, Remote Sens. Environ., 70, 191-207, 1999.
Weedon, G. P., Gomes, S., Viterbo, P., Shuttleworth, W. J., Blyth, E., Österle, H., Adam, J. C., Bellouin, N., Boucher, O., and Best, M.: Creation of the WATCH Forcing Data and Its Use to Assess Global and Regional Reference Crop Evaporation over Land during the Twentieth Century, J. Hydrometeorol., 12, 823-848, 2011.

Zeng, N.: Enhancement of Interdecadal Climate Variability in the Sahel by Vegetation Interaction, Science, 286, 1537-1540, 1999. 